\title{
Should they stay or should they go? \\ Attitudes towards immigration in Europe
}

\author{
Sarah Bridges* \\ (University of Nottingham) \\ Simona Mateut \\ (University of Nottingham)
}

\begin{abstract}
This paper examines the main determinants of individual attitudes towards immigration in Europe. Our results suggest that both economic and non-economic variables shape attitudes towards immigration, but the relative importance of these factors depends crucially on the race/ethnicity of the arriving immigrants. While fears over labour market competition are more likely to shape attitudes towards the arrival of same race immigrants, more exposure to immigrants reduces opposition towards the arrival of different race immigrants. These findings persist after controlling for socioeconomic characteristics, and after exploiting the data to allow for cohort-specific effects.
\end{abstract}

Keywords: Attitudes, Immigration, European Union

JEL Classifications: F1, F22, J61

\section{Acknowledgements}

The authors are grateful for helpful comments received from S. Brown, R. Disney, S. McIntosh, K. Taylor, and participants at the EEA conference Barcelona, seminar participants at the Universities of Sheffield, Manchester, and Newcastle. All remaining errors are our own.

*Corresponding author: Sarah Bridges, School of Economics, University of Nottingham, University Park, Nottingham, NG7 2RD, UK. Tel: 44-115-8466715. Fax: 44-115-9514159. E-mail: sarah.bridges@ nottingham.ac.uk. 


\section{Introduction}

Immigration is often a hotly debated topic and one that is likely to loom large in political and media circles throughout Europe as worsening economic conditions take hold. Tensions between natives and immigrants are often portrayed, in the media at least, as being at their worse in an economic downturn as immigrants and natives compete for scarce jobs and public resources. With this in mind, this paper investigates the extent to which economic and non-economic factors shape attitudes towards immigration in Europe, and in doing so focuses on an issue that has received much less attention in the literature, namely the extent to which attitudes towards immigration vary with the race or ethnicity of the arriving immigrants.

A large literature has developed examining attitudes towards immigration, across a wide range of countries. ${ }^{1}$ Much of the empirical research in this area focuses on the economic effects of immigration and finds that attitudes towards the arrival of immigrants are strongly shaped by economic self-interest. Native workers appear to be more likely to oppose immigration when they feel threatened by labour market competition from migrants. Scheve and Slaughter (2001), for example, find that less-skilled individuals are more likely to oppose the arrival of immigrants (and vice versa), and argue that attitudes towards immigration are influenced by a person's position in the labour market. Similarly, Mayda (2006) finds that skilled individuals are more likely to favour immigration in countries where the relative skill composition of natives relative to immigrants is high (and vice versa). Such findings are consistent with the labour market predictions of the factor proportions model. ${ }^{2}$

In contrast, Hainmueller and Hiscox (2007), using European data, argue that the relationship between education (which is often used as a proxy for skill level) and attitudes towards immigrants has little to do with fears about labour market competition. They find that individuals with higher levels of education are more likely to favour immigration regardless of the immigrant's skill level or country of origin. Similarly, Citrin et al. (1997) find little role for personal economic circumstances in shaping attitudes towards immigrants, while Dustmann and Preston (2007) assert that racial prejudice is an important factor.

\footnotetext{
${ }^{1}$ See, for example, Hainmuller and Hiscox (2010), Facchini, et al. (2007), Kessler (2001), Scheve and Slaughter (2001), Citrin et al. (1997), and Espenshade and Hempstead (1996) for the US; Dustman and Preston (2001 and 2007) for the UK; Hainmuller and Hiscox (2007) for Europe; and Facchini and Mayda (2008) and Mayda (2006) for the US, Canada, Japan and a sample of countries in Europe.

${ }^{2}$ In other words, assuming that skilled and unskilled workers are complements, if natives are more skilled than immigrants, immigration should reduce the supply of skilled workers relative to unskilled workers and raise the skilled wage, whereas the opposite is true in countries with a low skill composition of natives relative to immigrants.
} 
Welfare considerations are also important in shaping attitudes towards immigration. Hanson et al. (2007) using data for the US find that exposure to fiscal pressure from migrants' increases opposition towards immigration, especially among the more skilled. In a cross-country analysis, Facchini and Mayda (2009) show that individuals on a high income are more likely to oppose immigration in countries where immigrants are unskilled and therefore potentially represent a net burden to the welfare state (and vice versa when immigrants are skilled). Dustmann and Preston (2007) also find that welfare concerns play a major role in determining attitudes towards immigration.

With a few exceptions, the literature tends to assume that natives view all immigrants in the same way. ${ }^{3}$ Attitudes towards immigration are however likely to vary with the race or ethnicity of the arriving immigrants, especially if the arriving immigrants are of a different race or ethnicity to the dominant race/ethnic group within a country. Thus grouping all immigrants together and pooling across countries is likely to produce unreliable results. This is likely to be particularly true in Europe where the composition of the immigrant population varies widely across countries.

We attempt to address these limitations by conducting an analysis of attitudes towards immigration using data from the European Social Survey (ESS), a particularly rich data set for examining some of the issues surrounding immigration. Above all, the ESS enables us to investigate the extent to which attitudes are affected by the race or ethnicity of the arriving immigrants. In addition, although the ESS is not a panel and hence the same individuals cannot be tracked over time we are, nevertheless, able to use the data to construct a pseudo panel (see Deaton, 1985) and track different 'cohorts' over time in order to eliminate any unobserved fixed effects.

A common way to gauge the impact foreign workers have on the domestic labour market is to control for the relative income and education level (as a proxy for skill) of the native population. We refine this approach and match in data from the European Union Labour Force Survey (EU LFS) to examine the effect the size of the immigrant population has on attitudes towards immigration. Indubitably there are two effects at work in this context. Firstly, attitudes are likely

\footnotetext{
${ }^{3}$ Dustmann and Preston (2007) use data from the British Social Attitudes Survey and distinguish among immigrants from four origin regions: the West Indies, India and Pakistan, countries in the European common market, and Australia and New Zealand. Hainmueller and Hiscox (2007) use data from a single wave of the European Social Survey to investigate whether attitudes towards immigration depend on the origin of immigrants (from richer or poorer countries both in and outside Europe), while Hainmueller and Hiscox (2010) use data from a survey experiment to investigate the role played by the immigrants' skill level.
} 
to be shaped by exposure to immigrants in daily life. ${ }^{4}$ Secondly, natives may be more likely to oppose immigration when they feel threatened by labour market competition from migrants, since it is likely to induce downward pressure on labour market opportunities and wages. We attempt to separate these conflicting effects by controlling for both the proportion of non-nationals in the respondent's region and the proportion of non-nationals in each occupation. We argue that the former proxies for the degree of contact respondents have with immigrants, while the latter captures the competition effect.

We find that contact is important in shaping attitudes towards immigration, but mainly towards those of a different race or ethnic group to the dominant group within a country. In general, more exposure to immigrants appears to reduce opposition towards the arrival of different race/ethnicity immigrants, but perhaps not surprisingly has little effect on attitudes towards the arrival of those of the same race or ethnicity. In contrast, we find evidence of a positive association between our proxy for labour market competition and a restrictive immigration policy (Mayda, 2006, finds a similar result). However, once again race/ethnicity has an important role to play. Natives appear to regard immigrants of the same race or ethnicity as representing a greater 'threat' to their labour market opportunities than those of a different race or ethnicity. This result is also correlated with education levels, and we find that highly educated Europeans (those with a post-secondary education) appear to only perceive labour market competition from immigrants of the same race or ethnicity.

Finally, we show that public finance considerations are also important in shaping attitudes towards immigration, but mainly towards those of a different race/ethnicity. Immigrants of a different race/ethnicity to the native population appear to be perceived as being more likely to make use of public funds than immigrants of the same race/ethnicity. Dustmann and Preston (2007) make a similar finding in their study of the UK.

Taking these results together the following tentative 'story' emerges. An individual's attitude towards immigration is a complex interplay of factors. It is not just shaped by economic selfinterest, but also by non-economic factors, such as a fear of the unknown, cultural considerations, and welfare concerns. However, perhaps more than most, this study highlights that the relative importance of any factor, be it economic or non-economic, in shaping attitudes towards immigration depends crucially on the race/ethnicity of the arriving immigrants and hence on the size and nature of the immigrant population. Such a finding persists after controlling for

\footnotetext{
${ }^{4}$ More exposure may either increase or decrease the perceived threat posed by immigrants (Card et al., 2005).
} 
socioeconomic characteristics and exploiting the data to allow for cohort-specific effects.

The remainder of this paper is organized as follows. Section 2 illustrates our data and presents some summary statistics. In Section 3, we present our methodology. Section 4 outlines our main empirical results, while in Section 5 we conclude.

\section{Data}

This paper uses data from a number of sources: data on attitudes towards immigration is drawn from the European Social Survey (ESS), while information on country performance is obtained from Eurostat. The ESS is a biennial survey carried out in over 30 countries in Europe. The aim of this survey is to examine attitudes, beliefs and values across countries in Europe and some of its close neighbours, and how they change over time and across countries. We use three rounds of the $\mathrm{ESS}^{5}: 2001 / 2002,2003 / 2004$ and 2005/2006 and focus on the countries for which we have at least two years worth of data, which includes: Austria, Belgium, Czech Republic, Denmark, Estonia, Finland, France, Germany, Great Britain, Greece, Ireland, Luxembourg, Netherlands, Norway, Poland, Portugal, Slovakia, Slovenia, Spain, Sweden, and Switzerland. ${ }^{6}$ Only individuals who are citizens of the country in which they are interviewed are sampled. Table 1a in the Appendix provides the structure of the repeated cross-sections.

The ESS is a particularly rich data set for examining some of the issues surrounding immigration and we use the answers to the following two questions to construct our measures of the respondent's attitude towards immigration: 1. 'To what extent do you think [country] should allow people of the same race or ethnic group as most [country] people to come and live here?', and 2. 'How about people of a different race or ethnic group from most [country] people?' The survey allows for four ordered responses to both questions: 'allow many to come and live here', 'allow some', 'allow a few', and 'allow none'.

In line with the existing literature (see for example, Hainmueller and Hiscox, 2007 and Facchini and Mayda, 2009) we classify those respondents who report that they want to 'allow none' or 'allow a few' as those who want to limit the arrival of further immigrants ( 0 otherwise). We use this variable to gauge attitudes towards further immigration regardless of the race or ethnicity of the arriving immigrants. We are also interested in the effect race or ethnic origin has

\footnotetext{
${ }^{5}$ The first round of the ESS had a specific extra module on migration and minority related issues not present in the other rounds. However, all rounds provide the overall attitudinal response of individuals to further immigration, and also direct responses to an array of questions concerning the perceived effect immigrants have on the economy.
} 
on attitudes towards further immigration. We therefore classify respondents who want to 'allow none' or 'allow a few' immigrants of the same race or ethnic group as those who want to limit the arrival of same race/ethnicity immigrants (0 otherwise), and those who want to 'allow none' or 'allow a few' immigrants of a different race or ethnic group as those who want to limit the arrival of different race/ethnicity immigrants ( 0 otherwise). We also analyse whether our main results are robust to alternative definitions of our dependent variables. For ease of notation we refer to immigrants as simply same race or different race.

The ESS also collects a host of information on the respondent's socioeconomic background which is potentially important in explaining attitudes towards further immigration. This includes information on social and political views, religious identity, household characteristics (including age, household size, level of education, parents' country of birth), area of residence (city versus rural) and income (our proxy for economic status).

We also match in data from the EU $\mathrm{LFS}^{7}$ to examine the effect the size of the immigrant population has on opposition to immigration. As already mentioned, there are likely to be two conflicting effects at work in this context: the size of the immigrant population may be acting as a proxy for both the level of contact that individuals face from migrants and the degree of labour market competition. We attempt to separate these conflicting effects by matching in data on the proportion of non-nationals in the respondent's region at NUTS level 2 (subdivisions of a country) and, for each country, the proportion of non-national workers in the respondent's occupation at the one-digit level (ten occupations). Both indicators are measured for each round of data. We argue that the former captures the contact effect, while the latter proxies for the effect of labour market competition level (Mayda, 2006 attempts to measure the effects of labour market competition in a similar manner). ${ }^{8}$

Since the regions defined at NUTS level 2 are rather big and often geographically diverse entities within a country, we also include data from Eurostat on the regional unemployment rate (again at NUTS level 2) and in all empirical models we cluster on region to control for other sources of heterogeneity. ${ }^{9}$ Finally, we match in information on country performance using data

\footnotetext{
${ }^{7}$ The EU LFS is a quarterly household survey carried out in all EU member states, candidate countries and EFTA countries (except Liechtenstein).

${ }^{8}$ Perfect separation of 'contact' and 'competition' effects is practically impossible, as natives both get to know nonnationals who work in the same occupation and also compete with them for jobs (and other resources) in the same region.

${ }^{9}$ We focus on the explanation of attitudes at the individual level while controlling for economic and non-economic regional characteristics. Markaki and Longhi (2012) follow a rather different approach and analyse the impact of regional characteristics on shaping attitudes towards immigration.
} 
from Eurostat. This includes expenditure on social protection as a percentage of GDP and total crimes recorded by the police as a proportion of the population. A full definition of the variables used in this paper is presented in Table 2a in the Appendix.

\subsection{Descriptive Statistics}

Table 1 outlines some simple descriptive statistics of the main variables. We report mean responses and depending on the nature of the question either standard deviations or, for the categorical variables, the number reporting the highlighted response.

\section{$<<$ Table 1 here $>>$}

The sample composition of the ESS is relatively constant over the three waves of the survey and is evenly split between males and females. The average respondent is in his/her mid-40s, and lives in the city in a household with at least one other member (the average household size is 2.6). The majority of respondents (around 60\%) have an education level of upper secondary or above, are in paid employment, and have an annual income of between $€ 12,000$ and $€ 36,000$.

Turning to our measures of attitudes towards immigration we find that although $47 \%$ (in 2002) of respondents want to limit the arrival of immigrants, they appear more likely to want to limit the arrival of immigrants of a different race than those of the same race: 45\% (in 2002) want to limit the arrival of immigrants of a different race compared with only $32 \%$ for those of the same race.

Disaggregating some of these responses by country (Table 2) we find that there is substantial cross-country variation in attitudes towards immigration. Respondents in Greece want to limit the arrival of immigrants the most. At the other end of the spectrum, respondents in Sweden, Switzerland and Ireland appear to be more pro-immigration.

\section{$<<$ Table 2 here $>>$}

A common finding across all countries, even our pro-immigration countries, is that respondents are more likely to oppose the arrival of immigrants of a different race compared to those of the same race. However, differences emerge in the extent to which countries prefer immigrants of the same race compared with those of a different race. The Nordic countries (here Finland, Norway and Denmark) appear more prejudiced towards the arrival of different race immigrants while the UK appears to be tolerant towards immigrants regardless of their race or ethnicity. Such findings may be reflective of the immigration histories of these countries. The leading foreign group within each country often reflects historical links, relationships with former 
colonies and ease of access (in terms of geography or immigration policy). The UK, for example, has a long history of immigration as a result of its colonial past, most notably from the Indian subcontinent and the Caribbean (Hansen, 2003). In contrast, given its geographical position and close connection to Russia a high percentage of immigrants to Finland are from neighbouring Russia, while immigrants to Denmark come from its close neighbours Poland, Germany and Norway (Herm, 2008).

Next we investigate how attitudes towards immigration are affected by the proportion of nonnationals in the respondent's region (columns 10, 11 and 12). Overall we find evidence of a negative correlation between the proportion of non-nationals in the respondent's region and opposition towards immigration. This provides some initial evidence that contact plays a role in explaining attitudes towards immigration. In addition, this negative correlation is greater for opposition towards different race than same race immigrants, providing further support for the notion that the proportion of non-nationals in the respondent's region proxies for the degree of exposure natives have with immigrants. We argue that individuals fear what they do not know, or are unfamiliar with, so it follows that the more exposure natives have to immigrants in daily life, particularly those of a different race or ethnicity, the lower should be their opposition to further immigration.

Of course natives who have a negative view of immigration may avoid or have already left regions where the share of migrants is high. Schelling develops a dynamic model of segregation $(1971,1978)$ where each agent belongs to one of two groups. He shows that under certain assumptions the equilibrium condition is complete segregation, even if nearly everyone would 'prefer mixed neighbourhoods'. Schelling argues that if the proportion of group 2 residences exceeds some 'tolerance' limit or tipping point, this will cause the group 1 residents to move out of the neighbourhood to an alternative location. There is, however, little empirical evidence that immigration leads to the displacement of natives in either US data (Card and DiNardo, 2000; Card, 2001) or in European data (Gonzalez and Ortega, 2009), and we would argue that concerns about labour market opportunities, together with family history dominate the decision about where to live.

However, an alternative explanation for these findings is that immigrants may prefer to migrate to countries or regions that are less opposed to immigration. The popularity of some of our countries (e.g., the UK) as a destination for different race immigrants might be partially due to liberal attitudes of the native population towards immigration, or liberal immigration policies 
that are determined by these attitudes. This explanation holds for some of our countries where the correlation between the proportion of non-nationals in the respondent's region and opposition towards immigration is negative. However, within certain countries this correlation coefficient is positive (especially in relation to those of a different race), and for these countries it is doubtful that immigrants would choose to migrate to countries where opposition to immigrants is high. On a related issue, Dustman and Preston (2001) argue that ethnic minorities are unlikely to choose to live in areas where there is a high degree of racial intolerance. The countries where the correlation coefficient is positive tend to be those where large-scale immigration is a recent phenomenon (e.g., Greece, Spain, and Portugal), and we investigate this finding further in what follows.

\section{Empirical methodology}

\subsection{Probit}

We begin our multivariate analysis by estimating the probability that individual $i$ wants to limit the arrival of further immigrants $\left(y_{i t}=1\right)$ using a latent variable model of the form:

$$
y_{i t}^{*}=X_{i t}^{\prime} \beta_{1}+\alpha_{i}+u_{i t} \quad t=1, \ldots, T \quad \text { and } \quad i=1, \ldots, N_{t}
$$

where $y_{i t}^{*}$ is the latent propensity that individual $i$ favours a restrictive immigration policy, $X_{i t}$ are the set of regressors thought to affect immigration including the country specific effects, $\alpha_{i}$ represents the unobserved individual specific effect, and $u_{i t}$ is a random error that is distributed standard normally. Since different individuals are observed in each period this implies that $i$ runs from 1 to $N_{t}$ for time period t. All specifications have robust standard errors clustered on region to address heteroskedasticity and to allow for any correlation across individuals within the same region.

Our models include controls for economic variables (labour market competition, employment status, and income), non-economic variables (the degree of contact with immigrants, political ideology, and religion), and objective measures (the regional unemployment rate, expenditure on social security protection as a percentage of GDP, and the crime rate).

The ESS is not a panel and hence individuals are not 'tracked' over time. We thus initially assume that the individual fixed effects are uncorrelated with the observed regressors and pool our observations across the three waves of data. 


\subsection{Pseudo Panel}

Even though we cannot observe the same individual over time, we can, however, use the data to construct a pseudo panel (Deaton, 1985) and follow different cohorts over time in order to estimate relationships based on cohort means. This relaxes the assumption that the individual fixed effects are uncorrelated with some or all of the explanatory variables. ${ }^{10}$ This methodology has been widely used in applied research (Attanasio, 1993, for example, examines household savings in the US; Deaton, 1997, looks at consumption patterns in Taiwan; and Pencavel, 1998, analyses labour markets in the US).

Following Deaton (1985) we define a set of $C$ cohorts such that in any time $t$ individual $i$ only belong to one of these cohorts. The observed cohort means then satisfy the relationship:

$$
\bar{y}_{c t} \equiv \bar{X}_{c t}^{\prime} \beta_{2}+\bar{\alpha}_{c t}+\bar{u}_{c t} \quad c=1, \ldots, C
$$

where $\bar{y}_{c t}$ is the average of $y_{i t}$ for all members of cohort $c$ at time $t$ and $\bar{\alpha}_{c t}$ are the cohort fixed effects. Since we are not tracking the same individuals over time, $\bar{\alpha}_{c t}$ is not constant over time $t$. Despite this, Deaton (1985) argues that if the cohort size is sufficiently large then $\bar{\alpha}_{c t}$ is a good approximation for the cohort population $\bar{\alpha}_{c}$. We thus estimate equation (2) by replacing $\bar{\alpha}_{c t}$ with a set of dummy variables, one for each cohort.

Finally, Deaton (1985) also asserts that there is potentially a measurement error problem arising from using $\bar{y}_{c t}$ as an estimate of the unobservable population cohort mean and argues that equation (2) should be estimated using an errors in variable technique. However, as the cohort size increases, measurement error becomes less of a problem and this approach is typically ignored if the number of observations per cohort $\left(n_{c}\right)$ is sufficiently 'large' (see, for example, Browning et al., 1985 and Blundell et al., 1993). ${ }^{11}$ There is, however, no general rule to judge whether the number of observations per cohort is large enough to use asymptotics based on $\mathrm{n}_{\mathrm{c}}$. Verbeek (2008) argues that the asymptotic behaviour of pseudo panel estimators can be derived using an alternative type of asymptotics based on having a large number of cohorts of more or less constant size. In binary choice models, Collado (1998) shows that estimates need to rely on

\footnotetext{
${ }^{10}$ In a standard pooled probit model estimates are biased if the omitted/ unobserved variables are correlated with any of the regressors. Attitudes towards immigrants are, however, likely to be closely related to unobserved factors related to the native's upbringing, which is likely to be correlated with observable characteristics such as income and education.

${ }^{11}$ Verbeek and Nijman (1992) suggest that in a cohort comprising of 100 individuals where the time variation in the cohort means is sufficiently large, the bias in the standard fixed effects estimator will be small enough that the measurement error problem can be ignored.
} 
asymptotics based on a large number of cohorts. She further demonstrates that by doing so it is possible to obtain a consistent within-groups estimator for binary choice models.

Since we are interested in estimating a binary choice model, the important dimension of our pseudo panel is the large number of cohorts. We define the cohorts based on ten-year interval age groups, one-digit NACE economic sectors, and one-digit ISCO88 occupation groups. ${ }^{12}$ The tenyear age intervals allow for unobserved differences in the quality of education, skills and attitudes, and for homogeneity within groups and heterogeneity between groups. The first age group includes individuals born before 1937. These respondents are at least 65 years old in the first round of the ESS and are likely to be retired throughout the sample period. The second age group comprises of individuals born in the period 1938-1947, and so on until the sixth age group which is made up of respondents born after 1977. Individuals in each of the six age groups are then divided according to their occupation and the economic sector in which they have their main activity. $^{13}$

Variables on which cohorts are defined should be time-invariant and observed for all individuals in the sample. They should be appropriately correlated with the variables used in the model but uncorrelated with the unobservables (Verbeek, 2008). One could argue that, in our context, an individual's economic sector and occupation is subject to choice, and thus potentially endogenous. For instance, individuals who dislike immigrants may leave an occupation if the share of migrants becomes large. Despite this, we feel that the endogeneity of these variables is potentially low in our case. Individuals acquire specific labour market skills and as such changing occupation or economic sector would involve large retraining costs. Moreover, both economic sector and occupation are used at a high aggregation level.

We can construct a maximum theoretical number of 864 cohorts from our data: 6 (age groups) x 16 (economic sectors) $\mathrm{x} 9$ (occupations) $=864$ cohorts for each ESS round. ${ }^{14}$ As we do not observe individuals from each birth cohort in each occupation and economic sector in all three rounds, we have an unbalanced panel of 2,035 observations for a total of 710 cohorts. The average cohort is based on 80 individuals, which is large enough to reduce the potential measurement error discussed above. We estimate equation (2) by weighted least squares as is

\footnotetext{
12 This classification refers to the individuals' last job for those not currently working and their parents' job for young people still in full-time education. Our results hold if we drop the small proportion of young people in fulltime education.

${ }^{13}$ Variables used in the literature to define cohorts include: age (Deaton, 1985); age and education (Blundell et al., 1998); age and region (Propper et al., 2001).

${ }^{14}$ Individuals employed in extraterritorial organizations or whose occupations are in armed forces are excluded.
} 
standard in the literature (see, for example, Propper et al., 2001) since the average cohort size disguises large variation within cohorts. We also employ a fixed-effects estimator to eliminate any unobserved fixed cohort specific factors (age-sector-occupation effects). By construction, the pseudo panel controls for fixed economic sector, occupation, and age group differences. These variables are therefore excluded from the regression and we control for differences within cohorts only.

As an alternative specification, we could define the cohorts using country of residence, since as we have already shown attitudes towards immigration vary across countries. This would however cause the fixed effects to capture both the country specific factors together with the specific effects of the other variables used to define the cohorts. Since we want to include other country specific variables in our regressions, in this instance, we prefer to control for country specific effects explicitly through the presence of country dummies.

\section{Empirical Results}

Table 3 illustrates our results for a standard probit pooled over all observations and also for the fixed effects estimator. Results are reported for opposition towards the arrival of all immigrants, same race immigrants and different race immigrants, respectively. The explanatory variables are split into economic, non-economic (social and political), and household characteristics. We also include country and times dummies in all specifications. ${ }^{15}$ For each probit regression, the table provides details of marginal effects (evaluated at the means of the regressor variables) and levels of significance. The results that follow are robust to pooling over all observations and controlling for unobserved effects in a pseudo panel.

\section{$<<$ Table 3 here $>>$}

Of most interest in this context is the relationship between opposition towards immigration and the size of the immigrant population. We find evidence of a negative association between the proportion of non-nationals in the respondent's region and opposition towards the arrival of different race immigrants, which is in line with the summary statistics outlined in the previous section. We argue that one explanation for this finding is that individuals fear what they do not know, or are unfamiliar with, so it follows that more exposure to immigrants in daily life, especially those of a different race or ethnicity to the native population should decrease

\footnotetext{
${ }^{15}$ As in the pseudo panel each variable $\bar{x}_{c t}$ is constructed as the average of $x_{i t}$ for all members of cohort $c$ at time $t$ the country dummies are the percentage of individuals from a given country.
} 
opposition. In addition, we find that other variables which may also proxy for the degree of exposure native workers have with immigrants/ethnic minorities is also significant in this setting. We find that living in a city (pooled probit results) has a negative effect on opposition towards immigration, as does being born abroad or having at least one parent who was born abroad. On a related issue, Dustmann et al. (2011) show that in areas of higher local ethnic concentration, harassment towards minority groups is lower, even though overall hostility on the part of the population is not.

We also find evidence of a positive association between labour market competition and opposition towards immigration, which is more pronounced towards those of the same race than towards those of a different race. Natives thus appear to regard same race immigrants as representing a greater threat to their jobs than those of a different race. Such a finding is in line with expectations. Same race immigrants are likely to be similar to the native population in terms of educational background, skill, and experience. We investigate this finding further in the next sub-section when we disaggregate our results by educational attainment.

Turning to our other variables we find, in line with Facchini and Mayda (2009), that being on a higher income reduces opposition towards further immigration, although this effect is greater towards those of a different race than towards those of the same race. Non-economic factors also appear to be important in this setting and we find evidence of a negative relationship between those who report being religious (pooled probit) and opposition towards immigrants, while there is a positive association between individuals with a right-wing political ideology or who feel unsafe in the local area after dark (pooled probit) and wanting to limit the arrival of further immigrants, especially those of a different race.

Opposition towards the arrival of immigrants also arises on cultural grounds, and we find evidence of a positive relationship between individuals who feel that immigration is bad for a country's culture and those who want to limit the arrival of immigrants (Mayda, 2006, finds a similar result), especially those of a different race. Dustmann and Preston (2007) argue that prejudice of this kind may arise out of a fear for losing national characteristics or a taste for cultural homogeneity. Finally, we find a positive association between those natives who feel that immigrants are bad for the country and opposition towards immigration. ${ }^{16}$

\footnotetext{
${ }^{16}$ Although the attitudinal variables Immigrants are bad for the economy/culture/country are potentially endogenous in this setting since they may measure similar outcomes to the dependent variables, the correlation coefficients between these variables and our three dependent variables are relatively small (ranging from 0.29 to 0.51 ). In Section 4.3 we analyse the extent to which our main results are robust to the exclusion of these three variables.
} 
Next we investigate whether the belief that immigrants are bad for the country is linked to more 'objective' measures such as expenditure on social protection as a proportion of GDP (SSGDP) and the crime rate (Table 4).

\section{$<<$ Table 4 here $>>$}

We interact Immigrants are bad for the country with SSGDP and find evidence of a positive association between this variable and opposition towards different race immigrants (columns 4 and 10). Such a finding also holds if we interact Immigrants are bad for the country with the crime rate (columns 5 and 11). In other words, natives appear to believe that different race immigrants make the country a worse place to live, at least partly, through their impact on social security benefit and the crime rate. Respondents from countries with a higher ratio of social security expenditure to total GDP may, for example, fear that different race immigrants will benefit, at their expense, from their country's welfare state. There is evidence that immigrants are, on average, more likely than natives to be in receipt of welfare benefits (see Boeri, et al., 2002 for the EU and Hanson, et al., 2005 for the US). In contrast, for the UK, Dustmann et al. (2010) find that immigrants from Central and Eastern European countries that joined the European Union in May 2004 and who are eligible to claim benefits are less likely than the native population to do so. Similarly, natives appear to oppose different race immigration more as the crime rate in the host country increases, implying that immigrants of a different race/ethnic background contribute more to the crime rate. Although Butcher and Piehl (1998) find that immigrants to the US have much lower rates of criminality than natives, they may indirectly contribute to crime if immigration leads to increased group conflict, or if social tensions lead to harassment or violence towards the immigrant population.

\subsection{Immigration and Education}

We turn now to examine the extent to which opposition towards immigration is correlated with the respondent's education, and estimate our model separately for each level of education (Table 5). In this instance, we only present the pooled probit results since the average cohort size becomes too small if we separate by education level.

\section{$<<$ Table 5 here $>>$}

Here we find that for those with a post-secondary education the higher the proportion of nonnationals in a given region the less likely they are to oppose the arrival of different race immigrants. In addition, they only perceive labour market competition from same race 
immigrants, which may suggest that same race immigrants are more highly skilled than those of a different race. We find further indirect support for this hypothesis by examining data on education and country of birth from the EU LFS, which shows that immigrants born in an EU country have on average a higher level of education than natives and non-EU born immigrants (see Table 3a in the Appendix). ${ }^{17}$ Similarly, Dustmann and Preston (2007) using data for the UK argue that economic competition from potential immigrants is perceived more strongly by higher skilled natives.

\subsection{Immigration and Country}

Next, we look more closely at the extent to which opposition towards immigration is affected by a country's immigration history. Preliminary evidence outlined in Section 2 suggests that there is substantial cross-country variation in attitudes towards immigration, which may be reflective of the immigration histories of these countries. Here we split our countries into four groups based on their immigration history and/or geographical position.

At one end of the immigration spectrum we have a group of countries that have a long history of immigration either as a result of their colonial past and citizenship laws (UK, France, the Netherlands and Belgium), and/or post-war guest-worker policies (Austria, Switzerland, Germany, Belgium, the Netherlands, France, Denmark and Sweden). At the other end of the spectrum we have a sample of countries that only joined the EU in the middle of the sample period (May 2004), prior to which they were former Eastern Bloc countries, and thus have a much different immigration history. These countries, in particular, are currently providing an outflow of workers to the older EU member countries. ${ }^{18}$ See Hansen (2003) for a detailed review of the history of immigration to Europe.

We split our countries into the following four groups, and estimate the pooled probit regressions separately for each group (Table 6): (i) countries with a long history of immigration Austria, Belgium, Switzerland, Germany, France, UK and the Netherlands (Panel A); (ii) the new receiving countries - Spain, Greece, Ireland and Portugal (Panel B); (iii) new entrants to the EU from Eastern Europe - Czech Republic, Estonia, Slovenia, Slovakia and Poland (Panel C); and

\footnotetext{
${ }^{17}$ The data does not allow us to separate immigrants according to their race/ethnic origin; we only know whether immigrants were born in an EU or non-EU country. To find the closest match with the ESS we focus on data for 2007, the year of the last EU enlargement.

${ }^{18}$ These countries have either a very small or a negative rate (Poland) of net migration (see, Eurostat, demo_gind).
} 
(iv) the Nordic countries - Denmark, Finland, Norway and Sweden (Panel D). ${ }^{19}$

\section{$<<$ Table 6 here $>>$}

We find that labour market considerations do not seem to be an important factor in shaping attitudes towards immigration in the new receiving countries (Panel B). Moreover for these countries we find evidence of a positive association between opposition towards immigration, and the proportion of non-nationals in the respondent's region (for those with a mid-level education), which contrasts markedly with our countries in Panels A and B where the association is once again negative. We argue that such a finding for our Panel B countries is in line with their status as new immigration countries. Countries that are new to immigration often have an uneasy relationship with their immigrant population at the outset, and it takes time before immigrants become accepted as part of a country's usual demographic make-up. The UK, for example, in the late 1960s often had an uneasy relationship with its immigrant population. During the 1960s the number of immigrants from the Commonwealth countries more than doubled and led to Enoch Powell's now infamous anti-immigration speech, which received support from the general public. $^{20}$

We also conduct our welfare analysis for each of our four groups of countries. ${ }^{21}$ We find that while natives from groups $\mathrm{A}$ and $\mathrm{B}$ perceive that different race immigrants make their country a worse place to live through their impact on the country's public budget, respondents from the Nordic countries and Luxembourg (group D) have this fear towards same race immigrants, which may be reflective of the fact that the dominant foreign group in these countries are same race rather than different race immigrants.

\subsection{Robustness Tests}

We conduct a series of sensitivity tests on our main results. First, the summary statistics presented in Table 2 suggest that there is substantial cross-country variation in attitudes towards immigration. Greece appears to be anti-immigration, while at the other end of the spectrum Sweden appears to be pro-immigration. We find that excluding these two countries from our sample does not alter our results.

Second, in line with Facchini and Mayda (2009) and Mayda (2006), among others, all our

\footnotetext{
${ }^{19}$ See, for example, Boeri, et al. (2002) and Hansen (2003) for a review of the history of immigration to Europe, which helped to form the basis of these groupings.

${ }^{20}$ On the $20^{\text {th }}$ April 1968, a Conservative MP, Enoch Powell, spoke out against immigration from the Commonwealth in a speech that has since been called the 'Rivers of Blood' speech.

${ }^{21}$ These results are not reported for brevity, but are available upon request.
} 
models include the attitudinal variables Immigrants are bad for the economy/culture/country as control variables. As already mentioned, although these variables are potentially endogenous the correlation coefficients between them and our three dependent variables are relatively small. Despite this, we re-estimate all our models without these variables, and report the key findings in Table 7. Here panels 1 and 2 are equivalent to the main results outlined in Table 3, while panels 3 and 4 are equivalent to the result on welfare implications outlined in Table 4 . These results confirm our earlier findings. Namely that natives' attitudes towards immigration are influenced by labour market considerations but also by the proportion of non-nationals in the respondent's region (what we term contact with immigrants), but more so for different race immigrants.

Next, we experiment with a narrower definition of our dependent variables, and classify those respondents who report that they want to 'allow none' as those who want to limit the arrival of all immigrants, same race immigrants and different race immigrants, respectively. Now the proportion of respondents who oppose immigration in 2002 becomes 10\% (overall), $4.77 \%$ (same race) and 9.66\% (different race), which is lower than the proportions reported in Table 1 for the same year. Not surprisingly, the negative association we previously observed between the proportion of non-nationals in the respondent's region (our measure of contact) and opposition towards the arrival of different race immigrants becomes insignificant. However, when we conduct our analysis for groups of countries according to their immigration history and geographic position, our previous results still hold. We find evidence of a positive association between increased contact with immigrants and opposition towards the arrival of immigrants in the new host countries (Panel B) while we find evidence of a negative association on attitudes towards immigration for those countries with a long history of immigration (Panel A).

Finally, it might be the case that those individuals who are in paid employment or who are unemployed but actively searching for work are more concerned about the effects of labour market competition and the impact this may have on their wages and employment prospects than those who are out of the labour force (Hainmueller and Hiscox, 2007). We run separate regressions for the sub-sample of respondents in the labour force, and find that the coefficients on our variable measuring labour market competition are significantly larger compared to those reported in Table 3. 


\section{Conclusions}

This paper uses data from the European Social Survey and Eurostat to analyse the extent to which economic and non-economic variables affect opposition towards immigration in Europe. Simple cross-tabulations suggest a common finding across all countries in that respondents are more likely to want to limit the arrival of different race immigrants compared to those of the same race. However, differences emerge in the extent to which countries prefer immigrants of the same race compared with those of a different race. To explore these associations further we estimate a multivariate probit pooled over all observations and control for unobserved effects in a pseudo panel. After controlling for socioeconomic characteristics and allowing for cohortspecific effects, we find that the relative importance of economic and non-economic variables in shaping attitudes towards immigration depends crucially on the race of the arriving immigrants.

We find that the degree of contact that natives have had with immigrants is important in shaping attitudes towards further immigration, but only towards those of a different race. These findings are often reflective of a country's immigration history. In contrast, we find that fears over labour market competition are more likely to fuel opposition towards same race immigrants. Natives appear to regard same race immigrants as representing a greater 'threat' (whether perceived or actual) to their labour market opportunities than those of a different race. In contrast, immigrants of a different race are perceived to have a more negative impact on the country's culture. Finally, in line with Dustmann and Preston (2007), we find evidence that social welfare considerations are also important in determining attitudes towards further immigration, but mainly towards those of a different race.

In conclusion, immigration is clearly a very emotive issue and understanding how individuals perceive arriving immigrants is undoubtedly important in shaping a country's immigration policy. None more so is this important than within the EU where the free movement of persons is a general right. However, perhaps more than most, this paper highlights that governments need understand the complex interplay of factors that can fuel attitudes towards immigration within their own specific countries, and caution should be met at any attempt to adopt a one size fits all policy to immigration within the EU as is currently being debated. 


\section{References}

Attanasio, O. (1993). A cohort analysis of saving behavior by US households, NBER Working Papers.

Blundell, R., Meghir, C. and Neves, P. (1993). Labour supply and intertemporal substitution, Journal of Econometrics 59, 137-160.

Blundell, R., Duncan, A. and Meghir, C. (1998). Estimating labor supply responses using tax reforms, Econometrica 66, 827-861.

Boeri, T., Hanson, G. and McCormick, B. (2002). Immigration policy and the welfare system: Report for the Fondazione Rodolfo, Oxford: Oxford University Press.

Browning, M., Deaton, A. and Irish, M. (1985). A profitable approach to labour supply and commodity demand over the life-cycle, Econometrica 53, 503-543.

Card, D. (2001). Immigrant inflows, native outflows, and the local labor market impacts of higher immigration. Journal of Labor Economics XIX, 22-64.

Card, D., and DiNardo, J. (2000). Do immigrant inflows lead to native outflows, The American Economic Review 90 (2), 360-367.

Card, D., Dustmann, C. and Preston, I. (2005). Understanding attitudes to immigration: The migration and minority module of the first European Social Survey, CReAM Discussion Paper No 03/05.

Citrin, J., Green, D., Muste, C. and Wong, C. (1997). Public opinion toward immigration reform: The role of economic motivations, Journal of Politics 59 (3), 858-881.

Collado, M. (1998). Estimating binary choice models from cohort data, Investigaciones Economicas 22 (2), 259-276.

Deaton, A. (1985). Panel data from a time-series of cross-sections, Journal of Econometrics 30, 109-126.

Deaton, A. (1997). The Analysis of Household surveys: A Microeconometric Approach to Development Policy, Baltimore and London, World Bank.

Dustmann, C. and Preston, I. (2001). Attitudes to ethnic minorities, ethnic context and location decisions, The Economic Journal 111(470), 353-373.

Dustmann, C. and Preston, I. (2007). Racial and economic factors in attitudes to immigration, The B.E. Press Journal of Economic Analysis \& Policy 7(1) (Advances), Article 62.

Dustmann, C., Frattini, T. and Halls, C. (2010). Assessing the fiscal costs and benefits of A8 migration to the UK, Fiscal Studies 31(1), 1-41.

Dustmann, C., Fabbri, F. and Preston, I. (2011). Racial harassment, ethnic concentration, and economic conditions, The Scandinavian Journal of Economics 113(3), 689-711.

Espenshade, T., and Hempstead, K. (1996). Contemporary American attitudes toward U.S. immigration, International Migration Review 30, 535-570.

Facchini, G., and Mayda, A. M. (2009). Does the welfare state affect individual attitudes toward immigrants? Evidence across countries, The Review of Economics and Statistics 91, 295-314.

Facchini, G. and Mayda, A. M. (2008). From individual attitudes towards migrants to migration policy 
outcomes: Theory and evidence, Economic Policy 23, 651-713

Facchini, G., Mayda, A. M. and Mishra, P. (2007). Do interest groups affect immigration?, IZA Discussion Papers 3183, Institute for the Study of Labor (IZA).

González, L. and Ortega, F. (2011). How do very open economies adjust to large immigration flows? Evidence from Spanish regions, Labour Economics 18, 57-70.

Hansen, R. (2003). Migration to Europe since 1945: Its History and its Lessons, The Political Quarterly $74,25-38$.

Hanson, G., Scheve, K. and Slaughter, M. (2005). Public finance and individual preferences over globalization strategies. National Bureau of Economic Research, Working Paper 11028.

Hainmueller, J. and Hiscox, M. (2010). Attitudes towards highly skilled and low skilled immigration: Evidence from a survey experiment, American Political Science Review 104, 1-24.

Hainmueller, J. and Hiscox, M. (2007). Educated preferences: Explaining attitudes toward immigration in Europe, International Organization 61, 399-442.

Herm, A. (2008). Population and social conditions. Recent migration trends: citizens of EU-27 Member States become ever more mobile while EU remains attractive to non EU-citizens, Eurostat, Statistics in Focus, 98/2008.

Kessler, A. (2001). Immigration, economic insecurity, and the "ambivalent" American public, The Center for Comparative Immigration Studies Working Paper No. 41.

Mayda, A. M. (2006). Who is against immigration? A cross-country investigation of individual attitudes toward immigrants, The Review of Economics and Statistics 88(3), 510-530.

Markaki, Y. and Longhi, S. (2012). What determines attitudes to immigration in European countries? An analysis at the regional level, CReAM discussion paper 33/12

Pencavel, J. (1998). The market work behaviour and wages of women: 1975-94, Journal of Human Resources 33(4), 771-804.

Propper, C., Rees, H. and Green, K. (2001). The demand for private medical insurance in the UK: a cohort analysis, The Economic Journal 111(471), 180-200.

Schelling, T. (1971). Dynamic models of segregation, Journal of Mathematical Sociology 1 (July), 143186.

Schelling, T. (1978). Micromotives and Macrobehavior. New York: Norton.

Scheve, K. and Slaughter, M. J. (2001). Labor market competition and individual preferences over immigration policy, The Review of Economics and Statistics 83(1), 133-145.

Verbeek, M. and Nijman, T. (1992). Can cohort data be treated as genuine panel data?, in Raj, B. and Batalgi, B.H. (eds.), Panel Data Analysis, Physica-Verlag Heidelberg.

Verbeek, M. (2008). Pseudo panels and repeated cross-sections, in Mátyás, L. and Sevestre, P. (eds.), The Econometrics of Panel Data: Fundamentals and Recent Developments in Theory and Practice, Springer. 


\section{Appendix}

Table 1a: Pooled Sample

\begin{tabular}{|l|c|c|c|c|}
\hline Country & ESS Round 1 & ESS Round 2 & ESS Round 3 & Total \\
\hline Austria & 0 & 885 & 1,017 & 1,902 \\
Belgium & 971 & 1,050 & 1,265 & 3,286 \\
Switzerland & 1,135 & 1,247 & 1,122 & 3,504 \\
Czech Republic & 601 & 1,099 & 0 & 1,700 \\
Germany & 1,787 & 1,728 & 1,708 & 5,223 \\
Denmark & 1,053 & 1,095 & 1,131 & 3,279 \\
Estonia & 0 & 811 & 0 & 811 \\
Spain & 586 & 600 & 824 & 2,010 \\
Finland & 1,585 & 1,655 & 1,556 & 4,796 \\
France & 0 & 1,120 & 1,302 & 2,422 \\
United Kingdom & 1,455 & 0 & 1,515 & 2,970 \\
Greece & 980 & 998 & 0 & 1,978 \\
Ireland & 0 & 1,260 & 834 & 2,094 \\
Luxembourg & 323 & 493 & 0 & 816 \\
Netherlands & 1,683 & 1,380 & 1,414 & 4,477 \\
Norway & 1,566 & 1,532 & 1,487 & 4,585 \\
Poland & 0 & 925 & 949 & 1,874 \\
Portugal & 626 & 660 & 651 & 1,937 \\
Sweden & 1,544 & 1,439 & 4,501 \\
Slovenia & 695 & 568 & 696 & 1,959 \\
Slovakia & 0 & 21,146 & 19,635 & 1,247 \\
\hline Total & 16,590 & & 725 & 57,371 \\
\hline
\end{tabular}


Table 2a: Definition of Variables

\begin{tabular}{|c|c|}
\hline Variable & Definition \\
\hline Limit the arrival of immigrants & $\begin{array}{l}=1 \text { if respondents report that they want to 'allow none' or 'allow a few' to either of the above questions, } 0 \\
\text { otherwise. }\end{array}$ \\
\hline $\begin{array}{l}\text { Limit the arrival of same race } \\
\text { immigrants }\end{array}$ & $\begin{array}{l}=1 \text { if respondents report that they want to 'allow none' or 'allow a few' people of the same race or ethnic } \\
\text { group as most [country] people to come and live here, } 0 \text { otherwise. }\end{array}$ \\
\hline $\begin{array}{l}\text { Limit the arrival of different race } \\
\text { immigrants }\end{array}$ & $\begin{array}{l}=1 \text { if respondents report that they want to 'allow none' or 'allow a few' people of a different race or ethnic } \\
\text { group from most [country] people, } 0 \text { otherwise. }\end{array}$ \\
\hline $\begin{array}{l}\text { Proportion of non-nationals by } \\
\text { occupation }\end{array}$ & $\begin{array}{l}\text { Proportion of non-nationals in a given occupation by year at the 1-digit Standard Occupation Classification. } \\
\text { Source: European Union Labour Force Survey. }\end{array}$ \\
\hline $\begin{array}{l}\text { Proportion of non-nationals by } \\
\text { region }\end{array}$ & $\begin{array}{l}\text { Proportion of non-nationals in a given region by year (at NUTS level 2). The Nomenclature of territorial } \\
\text { units for statistics, abbreviated as NUTS, subdivides European countries into regions at three different levels } \\
\text { (NUTS } 1,2 \text { and 3, respectively), moving from larger to smaller territorial units. Source: European Union } \\
\text { Labour Force Survey. }\end{array}$ \\
\hline $\begin{array}{l}\text { Proportion of non-nationals by } \\
\text { education level }\end{array}$ & Proportion of non-nationals by education level and year. Source: European Union Labour Force Survey. \\
\hline Income & $\begin{array}{l}\text { The annual household income is coded in } 12 \text { intervals in thousand of Euros: } \mathrm{j} \text { (less than } € 1.8) ; \mathrm{r}(€ 1.8 \text { to } \\
\text { under } € 3.6) ; \mathrm{c}(€ 3.6 \text { to under } € 6) ; \mathrm{m}(€ 6 \text { to under } € 12) ; \mathrm{f}(€ 12 \text { to under } € 18) ; \mathrm{s}(€ 18 \text { to under } € 24) ; \mathrm{k}(€ 24 \text { to } \\
\text { under } € 30) ; \mathrm{p}(€ 30 \text { to under } € 36) ; \mathrm{d}(€ 36 \text { to under } € 60) ; \mathrm{h}(€ 60 \text { to under } € 90) ; \mathrm{u} \text { (€90 to under } € 120) ; \mathrm{n}(€ 120 \\
\text { or more). }\end{array}$ \\
\hline Income $>=€ 12,000$ and $<€ 36,000$ & $=1$ if annual household income $>=€ 12,000$ and $<€ 36,000$ (bands $\mathrm{f}, \mathrm{s}, \mathrm{k}$, and $\mathrm{p}$ ), 0 otherwise. \\
\hline Income $>=€ 36,000$ & $=1$ if annual household income $>=€ 36,000$ (bands $\mathrm{d}, \mathrm{h}, \mathrm{u}$ and $\mathrm{n}$ ), 0 otherwise. \\
\hline Employment Status: & \\
\hline Work & $=1$ if in paid work, 0 otherwise. \\
\hline Education & $=1$ if in education, 0 otherwise. \\
\hline Retired & $=1$ if retired, 0 otherwise. \\
\hline Unemployed & $=1$ if unemployed, looking for a job or unemployed, not looking for a job, 0 otherwise. \\
\hline Other & $\begin{array}{l}=1 \text { if permanently sick or disabled, in community or military service, doing housework, looking after } \\
\text { children, other, } 0 \text { otherwise. }\end{array}$ \\
\hline Male & $=1$ if male, 0 otherwise. \\
\hline Household size & Number of people living regularly as a member of the household. \\
\hline Upper secondary education & $=1$ if highest education level is upper secondary, 0 otherwise. \\
\hline Post-secondary education & $=1$ if highest education level is post-secondary and above, 0 otherwise. \\
\hline Foreign & $=1$ if born abroad or if one or both parents were born abroad, 0 otherwise. \\
\hline City & $\begin{array}{l}=1 \text { if the respondent lives in a big city, the suburbs or outskirts of a big city, a town or small city, } 0 \\
\text { otherwise. }\end{array}$ \\
\hline Non-1 & \\
\hline $\begin{array}{l}\text { Immigrants are bad for the } \\
\text { economy }\end{array}$ & $\begin{array}{l}=1 \text { if response to the question: 'Would you say it is generally bad or good for [country]'s economy that } \\
\text { people come to live here from other countries?' }(0, \text { bad for the economy; ...; 10, good for the economy) is } \\
<5,0 \text { otherwise. }\end{array}$ \\
\hline $\begin{array}{l}\text { Immigrants are bad for the } \\
\text { country's culture }\end{array}$ & $\begin{array}{l}=1 \text { if response to the question: 'Would you say that [country]'s cultural life is generally undermined or } \\
\text { enriched by people coming to live here from other countries? }(0, \text { cultural life undermined; ...; } 10 \text {, cultural } \\
\text { life enriched) is }<5,0 \text { otherwise. }\end{array}$ \\
\hline $\begin{array}{l}\text { Immigrants are bad for the } \\
\text { country }\end{array}$ & $\begin{array}{l}=1 \text { if response to the question: 'Immigrants make country worse or better place to live' }(0, \text { worse place to } \\
\text { live; } \ldots ; 10 \text {, better place to live) is }<5,0 \text { otherwise. }\end{array}$ \\
\hline Religious & $\begin{array}{l}=1 \text { if response to the question: 'How religious are you', }(0, \text { not at all religious; } \ldots ; 10 \text {, very religious }) \text { is }>5 \text {, } \\
0 \text { otherwise. }\end{array}$ \\
\hline Right wing & $\begin{array}{l}=1 \text { if response to the question: 'In politics people sometimes talk of 'left' and 'right' } \ldots \text { where would you } \\
\text { place yourself on this scale, where } 0 \text { means the left and } 10 \text { means the right? }(0, \text { left; } \ldots ; 10 \text {, right)' is }>5,0 \\
\text { otherwise. }\end{array}$ \\
\hline Unsafe & $\begin{array}{l}=1 \text { if response is 'unsafe' or 'very unsafe' to the question: 'How safe do you }- \text { or would you - feel walking } \\
\text { alone in this area after dark?' ( } 1 \text {, very safe; } 2 \text {, safe; } 3 \text {, unsafe; } 4 \text { very unsafe), } 0 \text { otherwise. }\end{array}$ \\
\hline Objective measures & \\
\hline Regional unemployment & $\begin{array}{l}\text { Regional unemployment rate at NUTS level } 2 \text { for each country. Source: Eurostat, series reg_lfu3rt } \\
\text { (www.eurostat.org) }\end{array}$ \\
\hline SSGDP & Expenditure on social protection as a percentage of GDP. Eurostat, series spr_exp_gdp (www.eurostat.org) \\
\hline Crime rate & $\begin{array}{l}\text { Total crimes recorded by the police divided by population. Eurostat, series crim_gen and demo-pjan. } \\
\text { (www.eurostat.org) }\end{array}$ \\
\hline
\end{tabular}


Table 3a: Percentage of Employed People by Education and Country of Birth

\begin{tabular}{|c|c|c|c|c|}
\hline $\begin{array}{l}\text { Highest level of } \\
\text { educational } \\
\text { attainment: }\end{array}$ & All & Nationals & $\begin{array}{l}\text { Born in an EU } \\
\text { country }\end{array}$ & $\begin{array}{l}\text { Born in a non-EU } \\
\text { country }\end{array}$ \\
\hline Up to secondary & 0.23 & 0.22 & 0.21 & 0.28 \\
\hline Upper secondary & 0.49 & 0.50 & 0.45 & 0.42 \\
\hline Post-upper secondary & 0.28 & 0.28 & 0.34 & 0.30 \\
\hline Total & 1.00 & 1.00 & 1.00 & 1.00 \\
\hline
\end{tabular}


Table 1: Summary Statistics

\begin{tabular}{|c|c|c|c|c|c|c|}
\hline Year & \multicolumn{2}{|c|}{2002} & \multicolumn{2}{|c|}{2004} & \multicolumn{2}{|c|}{2006} \\
\hline Number of observations & & & & & & \\
\hline Variable & Mean & $\begin{array}{l}\text { Std. Dev } \\
\text { or } n=x\end{array}$ & Mean & $\begin{array}{l}\text { Std. Dev } \\
\text { or } n=x\end{array}$ & Mean & $\begin{array}{c}\text { Std. Dev } \\
\text { or } n=x\end{array}$ \\
\hline $\begin{array}{l}=1 \text { if want to limit the arrival of immigrants, } 0 \\
\text { otherwise } \\
=1 \text { if want to limit the arrival of same race } \\
\text { immigrants, } 0 \text { otherwise } \\
=1 \text { if want to limit the arrival of different race } \\
\text { immigrants, } 0 \text { otherwise }\end{array}$ & 0.315 & 7,738 & 0.459 & 9,979 & 0.450 & $\begin{array}{l}5,664 \\
8,583\end{array}$ \\
\hline Economic: & & & & & & \\
\hline Proportion of non-nationals by occupation & 0.059 & 0.077 & 0.066 & 0.088 & 0.052 & 0.058 \\
\hline Proportion of non-nationals by education & 0.102 & 0.079 & 0.109 & 0.088 & 0.104 & 0.066 \\
\hline Proportion of non-nationals by region & 0.056 & 0.081 & 0.066 & 0.089 & 0.058 & 0.071 \\
\hline Income $<€ 12,000$ & 0.173 & 3,286 & 0.238 & 5,469 & 0.199 & 3,755 \\
\hline Income $>=€ 12,000$ and $\langle € 36,000$ & 0.516 & 8,243 & 0.504 & 9,700 & 0.496 & 9,330 \\
\hline Income $>=€ 36,000$ & 0.310 & 5,061 & 0.259 & 5,977 & 0.305 & 6,550 \\
\hline Employment status: & & & & & & \\
\hline$=1$ if unemployed, 0 otherwise & 0.045 & 603 & 0.060 & 1,044 & 0.046 & 774 \\
\hline$=1$ if in paid work, 0 otherwise & 0.576 & 9,705 & 0.573 & 12,056 & 0.595 & 11,598 \\
\hline$=1$ if in education, 0 otherwise & 0.040 & 791 & 0.038 & 877 & 0.035 & 811 \\
\hline$=1$ if retired, 0 otherwise & 0.198 & 3,363 & 0.221 & 4,874 & 0.208 & 4,233 \\
\hline $\begin{array}{l}\text { or military service, doing housework, looking after } \\
\text { children, others, } 0 \text { otherwise. }\end{array}$ & 0.142 & 2,128 & 0.109 & 2,295 & 0.115 & 2,219 \\
\hline Regional unemployment rate & 0.063 & 0.039 & 0.081 & 0.047 & 0.071 & 0.040 \\
\hline Non-Economic/Attitudinal: & & & & & & \\
\hline Immigrants are bad for the economy & 0.351 & 5,565 & 0.383 & 8,019 & 0.344 & 6,255 \\
\hline Immigrants are bad for the county's culture & 0.232 & 3,723 & 0.255 & 5,594 & 0.276 & 4,729 \\
\hline Immigrants are bad for the country & 0.367 & 5,803 & 0.351 & 7,500 & 0.356 & 6,302 \\
\hline Religious (= 1 if religious, 0 otherwise) & 0.368 & 6,583 & 0.391 & 8,727 & 0.366 & 7,821 \\
\hline $\begin{array}{l}\text { Right wing (= } 1 \text { if right wing political ideology, } 0 \\
\text { otherwise) }\end{array}$ & 0.303 & 5,773 & 0.304 & 7,419 & 0.312 & 6,805 \\
\hline Male & 0.517 & 8,630 & 0.511 & 10.603 & 0.517 & 9891 \\
\hline Age (years) & 47.24 & 16.62 & 46.99 & 16.59 & 47.56 & 16.79 \\
\hline Household size & 2.731 & 1.318 & 2.851 & 1.365 & 2.814 & 1.363 \\
\hline $\begin{array}{l}\text { Foreign (= } 1 \text { if born abroad or have at least one } \\
\text { parent who was born abroad, } 0 \text { otherwise })\end{array}$ & 0.110 & 1,825 & 0.106 & 2,386 & 0.118 & 2,217 \\
\hline $\begin{array}{l}=1 \text { if lives in the city, } 0 \text { otherwise } \\
\text { Educational attainment: }\end{array}$ & 0.669 & 10,258 & 0.636 & 13,013 & 0.654 & 12,129 \\
\hline$=1$ if primary, 0 otherwise & 0.319 & 5,354 & 0.333 & 6,841 & 0.347 & 6,336 \\
\hline $\begin{array}{l}=1 \text { if highest education level is upper secondary, } 0 \\
\text { otherwise. }\end{array}$ & 0.379 & 6,446 & 0.343 & 7,810 & 0.265 & 6,010 \\
\hline $\begin{array}{l}=1 \text { if highest education level is post-secondary and } \\
\text { above, } 0 \text { otherwise. } \\
\text { Country Characteristics: }\end{array}$ & 0.302 & 4,790 & 0.325 & 6,495 & 0.388 & 7,289 \\
\hline Social security benefits as a percentage of GDP & 0.253 & 0.029 & 0.249 & 0.049 & 0.257 & 0.040 \\
\hline Crime rate & 0.075 & 0.028 & 0.066 & 0.030 & 0.070 & 0.028 \\
\hline
\end{tabular}


Table 2: Attitudinal Responses Disaggregated by Country

\begin{tabular}{|c|c|c|c|c|c|c|c|c|c|c|c|c|}
\hline \multirow[b]{2}{*}{ Year } & \multicolumn{3}{|c|}{ Limit the arrival of immigrants } & \multicolumn{3}{|c|}{$\begin{array}{c}\text { Limit the arrival of same race } \\
\text { immigrants }\end{array}$} & \multicolumn{3}{|c|}{$\begin{array}{c}\text { Limit the arrival of different race } \\
\text { immigrants }\end{array}$} & \multicolumn{3}{|c|}{$\begin{array}{c}\text { Correlation coefficient: Proportion } \\
\text { of non-nationals by region }\end{array}$} \\
\hline & 2002 & 2004 & 2006 & 2002 & 2004 & 2006 & 2002 & 2004 & 2006 & All & $\begin{array}{l}\text { Same } \\
\text { Race }\end{array}$ & $\begin{array}{l}\text { Different } \\
\text { Race }\end{array}$ \\
\hline \multicolumn{13}{|l|}{ Country } \\
\hline Austria & & 0.526 & 0.591 & & 0.307 & 0.345 & & 0.515 & 0.586 & -0.006 & -0.009 & -0.009 \\
\hline Belgium & 0.464 & 0.460 & 0.453 & 0.305 & 0.294 & 0.247 & 0.427 & 0.446 & 0.432 & 0.031 & 0.035 & 0.038 \\
\hline Switzerland & 0.364 & 0.373 & 0.407 & 0.191 & 0.155 & 0.157 & 0.347 & 0.369 & 0.400 & 0.037 & -0.017 & 0.046 \\
\hline Czech Republic & 0.549 & 0.625 & & 0.441 & 0.477 & & 0.516 & 0.584 & & -0.043 & -0.064 & -0.033 \\
\hline Denmark & 0.433 & 0.495 & 0.487 & 0.249 & 0.274 & 0.268 & 0.414 & 0.475 & 0.472 & -0.051 & -0.057 & -0.051 \\
\hline Germany & 0.531 & 0.532 & 0.462 & 0.252 & 0.197 & 0.140 & 0.515 & 0.521 & 0.455 & -0.057 & -0.084 & -0.053 \\
\hline Estonia & & 0.700 & & & 0.440 & & & 0.681 & & 0.005 & 0.026 & 0.002 \\
\hline Spain & 0.488 & 0.481 & 0.477 & 0.404 & 0.418 & 0.420 & 0.462 & 0.463 & 0.459 & 0.018 & 0.009 & 0.021 \\
\hline Finland & 0.653 & 0.633 & 0.603 & 0.421 & 0.420 & 0.383 & 0.638 & 0.618 & 0.591 & -0.032 & -0.024 & -0.029 \\
\hline France & & 0.496 & 0.501 & & 0.340 & 0.362 & & 0.470 & 0.478 & -0.111 & -0.079 & -0.109 \\
\hline United Kingdom & 0.496 & & 0.520 & 0.323 & & 0.388 & 0.477 & & 0.503 & -0.001 & -0.003 & -0.001 \\
\hline Greece & 0.888 & 0.825 & & 0.706 & 0.663 & & 0.886 & 0.819 & & 0.023 & -0.027 & 0.022 \\
\hline Ireland & & 0.351 & 0.286 & & 0.228 & 0.202 & & 0.326 & 0.261 & -0.059 & 0.004 & -0.058 \\
\hline Netherlands & 0.434 & 0.464 & 0.494 & 0.363 & 0.334 & 0.398 & 0.406 & 0.435 & 0.481 & -0.029 & -0.034 & -0.030 \\
\hline Norway & 0.459 & 0.448 & 0.422 & 0.286 & 0.230 & 0.219 & 0.431 & 0.422 & 0.408 & -0.092 & -0.093 & -0.076 \\
\hline Poland & & 0.406 & 0.321 & & 0.293 & 0.189 & & 0.379 & 0.305 & -0.028 & -0.045 & -0.020 \\
\hline Portugal & 0.636 & 0.654 & 0.625 & 0.547 & 0.535 & 0.569 & 0.626 & 0.629 & 0.609 & 0.044 & 0.047 & 0.036 \\
\hline Sweden & 0.171 & 0.166 & 0.147 & 0.100 & 0.109 & 0.097 & 0.163 & 0.159 & 0.136 & -0.051 & -0.046 & -0.052 \\
\hline Slovenia & 0.458 & 0.426 & 0.434 & 0.325 & 0.317 & 0.263 & 0.432 & 0.377 & 0.409 & 0.005 & -0.016 & 0.0001 \\
\hline Slovakia & & 0.377 & 0.441 & & 0.230 & 0.290 & & 0.343 & 0.404 & -0.073 & -0.077 & -0.069 \\
\hline Overall & 0.471 & 0.480 & 0.476 & 0.315 & 0.317 & 0.314 & 0.451 & 0.459 & 0.450 & -0.009 & -0.036 & -0.005 \\
\hline
\end{tabular}


Table 3: Estimates of Opposition towards Further Immigration

\begin{tabular}{|c|c|c|c|c|c|c|}
\hline \multirow[b]{2}{*}{ Variable } & \multicolumn{3}{|c|}{ Pooled Probit } & \multicolumn{3}{|c|}{ Pseudo Panel } \\
\hline & All & Same Race & Different Race & All & Same Race & Different Race \\
\hline Proportion of non-nationals by occupation & $\begin{array}{c}0.184 * * * \\
(0.061)\end{array}$ & $\begin{array}{c}0.223 * * * \\
(0.064)\end{array}$ & $\begin{array}{c}0.184 * * * \\
(0.060)\end{array}$ & & & \\
\hline Proportion of non-nationals by education & & & & $\begin{array}{l}-0.141 \\
(0.267)\end{array}$ & $\begin{array}{c}1.076^{* * * *} \\
(0.268)\end{array}$ & $\begin{array}{l}-0.390 \\
(0.268)\end{array}$ \\
\hline Proportion of non-nationals by region & $\begin{array}{c}-0.203 * * \\
(0.103)\end{array}$ & $\begin{array}{l}-0.113 \\
(0.094)\end{array}$ & $\begin{array}{c}-0.180 * \\
(0.098)\end{array}$ & $\begin{array}{c}-0.858 * * * \\
(0.306)\end{array}$ & $\begin{array}{l}-0.141 \\
(0.306)\end{array}$ & $\begin{array}{c}-0.719 * * \\
(0.307)\end{array}$ \\
\hline Income $>=€ 12,000$ and $<€ 36,000$ & $\begin{array}{c}-0.025 * * \\
(0.011)\end{array}$ & $\begin{array}{c}-0.019 * * \\
(0.008)\end{array}$ & $\begin{array}{c}-0.026^{* *} \\
(0.011)\end{array}$ & $\begin{array}{c}-0.098 * * * \\
(0.030)\end{array}$ & $\begin{array}{c}-0.100 * * * \\
(0.030)\end{array}$ & $\begin{array}{c}-0.112 * * * \\
(0.030)\end{array}$ \\
\hline Income $>=€ 36,000$ & $\begin{array}{c}-0.075^{* * *} \\
(0.014)\end{array}$ & $\begin{array}{c}-0.055^{* * * *} \\
(0.010)\end{array}$ & $\begin{array}{c}-0.069 * * * \\
(0.014)\end{array}$ & $\begin{array}{c}-0.292 * * * \\
(0.041)\end{array}$ & $\begin{array}{c}-0.204 * * * \\
(0.041)\end{array}$ & $\begin{array}{c}-0.302 * * * \\
(0.042)\end{array}$ \\
\hline Employment status (base case unemployed): & & & & & & \\
\hline$=1$ if in paid work, 0 otherwise & $\begin{array}{l}-0.001 \\
(0.023)\end{array}$ & $\begin{array}{c}-0.024 \\
(0.021)\end{array}$ & $\begin{array}{c}0.008 \\
(0.023)\end{array}$ & $\begin{array}{c}0.147 * * * \\
(0.050)\end{array}$ & $\begin{array}{l}-0.007 \\
(0.050)\end{array}$ & $\begin{array}{c}0.126^{* *} \\
(0.050)\end{array}$ \\
\hline$=1$ if in education, 0 otherwise & $\begin{array}{c}-0.113 * * * \\
(0.034)\end{array}$ & $\begin{array}{c}-0.106 * * * \\
(0.028)\end{array}$ & $\begin{array}{c}-0.103 * * * \\
(0.036)\end{array}$ & $\begin{array}{c}-0.190 * * * \\
(0.072)\end{array}$ & $\begin{array}{c}-0.210 * * * \\
(0.073)\end{array}$ & $\begin{array}{c}-0.132 * \\
(0.073)\end{array}$ \\
\hline$=1$ if retired, 0 otherwise & $\begin{array}{c}0.016 \\
(0.025)\end{array}$ & $\begin{array}{l}-0.023 \\
(0.023)\end{array}$ & $\begin{array}{c}0.028 \\
(0.023)\end{array}$ & $\begin{array}{c}0.231 * * * \\
(0.055)\end{array}$ & $\begin{array}{c}0.027 \\
(0.056)\end{array}$ & $\begin{array}{c}0.244 * * * \\
(0.056)\end{array}$ \\
\hline $\begin{array}{l}=1 \text { if permanently sick or disabled, in community or military service, } \\
\text { doing housework, looking after children, others, } 0 \text { otherwise. }\end{array}$ & $\begin{array}{l}-0.004 \\
(0.029)\end{array}$ & $\begin{array}{l}-0.019 \\
(0.023)\end{array}$ & $\begin{array}{l}0.005 \\
(0.029)\end{array}$ & $\begin{array}{l}0.241 * * * \\
(0.057)\end{array}$ & $\begin{array}{l}-0.050 \\
(0.057)\end{array}$ & $\begin{array}{l}0.205 * * * \\
(0.057)\end{array}$ \\
\hline Regional unemployment rate & $\begin{array}{l}-0.070 \\
(0.133)\end{array}$ & $\begin{array}{c}0.110 \\
(0.153)\end{array}$ & $\begin{array}{l}-0.078 \\
(0.156)\end{array}$ & $\begin{array}{c}0.216 \\
(0.370)\end{array}$ & $\begin{array}{c}0.354 \\
(0.371)\end{array}$ & $\begin{array}{c}0.067 \\
(0.371)\end{array}$ \\
\hline Non-Economic/Attitudinal: & & & & & & \\
\hline Immigrants are bad for the economy & $\begin{array}{c}0.202 * * * \\
(0.011)\end{array}$ & $\begin{array}{c}0.157 * * * \\
(0.009)\end{array}$ & $\begin{array}{c}0.204 * * * \\
(0.011)\end{array}$ & $\begin{array}{c}0.132 * * * \\
(0.026)\end{array}$ & $\begin{array}{c}0.082 * * * \\
(0.026)\end{array}$ & $\begin{array}{c}0.162 * * * \\
(0.026)\end{array}$ \\
\hline Immigrants are bad for the county's culture & $\begin{array}{c}0.172 * * * \\
(0.009)\end{array}$ & $\begin{array}{c}0.122 * * * \\
(0.011)\end{array}$ & $\begin{array}{c}0.162 * * * \\
(0.009)\end{array}$ & $\begin{array}{c}0.142 * * * \\
(0.029)\end{array}$ & $\begin{array}{c}0.047 \\
(0.029)\end{array}$ & $\begin{array}{c}0.123 * * * \\
(0.029)\end{array}$ \\
\hline Immigrants are bad for the country & $\begin{array}{c}0.251 * * * \\
(0.008)\end{array}$ & $\begin{array}{c}0.173 * * * \\
(0.007)\end{array}$ & $\begin{array}{c}0.249 * * * \\
(0.007)\end{array}$ & $\begin{array}{c}0.287 * * * \\
(0.028)\end{array}$ & $\begin{array}{c}0.311^{* * * *} \\
(0.028)\end{array}$ & $\begin{array}{c}0.287 * * * \\
(0.028)\end{array}$ \\
\hline Religious ( $=1$ if religious, 0 otherwise) & $\begin{array}{c}-0.026 * * * \\
(0.009)\end{array}$ & $\begin{array}{c}-0.029 * * * \\
(0.006)\end{array}$ & $\begin{array}{c}-0.026 * * * \\
(0.008)\end{array}$ & $\begin{array}{c}0.035 \\
(0.025)\end{array}$ & $\begin{array}{c}0.015 \\
(0.025)\end{array}$ & $\begin{array}{c}0.041 \\
(0.025)\end{array}$ \\
\hline Right wing (= 1 if right wing political ideology, 0 otherwise) & $\begin{array}{c}0.086^{* * * *} \\
(0.011)\end{array}$ & $\begin{array}{c}0.021 * * * \\
(0.008)\end{array}$ & $\begin{array}{c}0.089 * * * \\
(0.012)\end{array}$ & $\begin{array}{c}0.125 * * * \\
(0.024)\end{array}$ & $\begin{array}{c}0.026 \\
(0.024)\end{array}$ & $\begin{array}{c}0.147 * * * \\
(0.024)\end{array}$ \\
\hline Unsafe (= 1 if feel unsafe walking in the local area after dark, 0 otherwise) & $\begin{array}{c}0.030 * * * \\
(0.011)\end{array}$ & $\begin{array}{c}0.019 * * \\
(0.008)\end{array}$ & $\begin{array}{c}0.028 * * * \\
(0.009)\end{array}$ & $\begin{array}{c}0.023 \\
(0.031)\end{array}$ & $\begin{array}{c}0.002 \\
(0.031)\end{array}$ & $\begin{array}{l}-0.001 \\
(0.031)\end{array}$ \\
\hline $\begin{array}{l}\text { Household Characteristics: } \\
\text { Male }\end{array}$ & $\begin{array}{c}0.007 \\
(0.009)\end{array}$ & $\begin{array}{l}-0.001 \\
(0.006)\end{array}$ & $\begin{array}{c}0.008 \\
(0.010)\end{array}$ & $\begin{array}{c}0.145 * * * \\
(0.025)\end{array}$ & $\begin{array}{c}0.015 \\
(0.025)\end{array}$ & $\begin{array}{c}0.146 * * * \\
(0.025)\end{array}$ \\
\hline
\end{tabular}




\begin{tabular}{|c|c|c|c|c|c|c|}
\hline $\begin{array}{l}\text { Age cohorts : } \\
\text { agegr } 2\end{array}$ & $-0.039 * * *$ & $-0.033 * * *$ & $-0.030 * *$ & & & \\
\hline agegr3 & $\begin{array}{c}(0.014) \\
-0.074 * * *\end{array}$ & $\begin{array}{c}(0.008) \\
-0.036 * * *\end{array}$ & $\begin{array}{l}(0.014) \\
061 * * *\end{array}$ & & & \\
\hline agegiJ & $\begin{array}{c}-0.0 / 4 \\
(0.020)\end{array}$ & $\begin{array}{c}-0.050 \\
(0.013)\end{array}$ & $\begin{array}{c}-0.001 \\
(0.020)\end{array}$ & & & \\
\hline agegr4 & $\begin{array}{c}-0.086^{* * * *} \\
(0.019)\end{array}$ & $\begin{array}{r}-0.024 * \\
(0.013)\end{array}$ & $\begin{array}{c}-0.075^{* * *} \\
(0.019)\end{array}$ & & & \\
\hline agegr5 & $\begin{array}{l}-0.096 * * * \\
(0.020)\end{array}$ & $\begin{array}{l}-0.027 \\
(0.017)\end{array}$ & $\begin{array}{c}-0.083^{* * *} * \\
(0.018)\end{array}$ & & & \\
\hline agegr6 & $\begin{array}{l}-0.111 * * * \\
(0.020)\end{array}$ & $\begin{array}{l}-0.058 * * * \\
(0.017)\end{array}$ & $\begin{array}{l}-0.103 * * * \\
(0.018)\end{array}$ & & & \\
\hline Household size & $\begin{array}{c}0.005 \\
(0.004)\end{array}$ & $\begin{array}{l}-0.000 \\
(0.003)\end{array}$ & $\begin{array}{l}0.005 \\
(0.004)\end{array}$ & $\begin{array}{c}0.023 * * \\
(0.010)\end{array}$ & $\begin{array}{c}0.059 * * * \\
(0.010)\end{array}$ & $\begin{array}{c}0.032 * * * \\
(0.010)\end{array}$ \\
\hline $\begin{array}{l}\text { Foreign ( }=1 \text { if born abroad or have at least one parent who was born } \\
\text { abroad, } 0 \text { otherwise) }\end{array}$ & $\begin{array}{l}-0.010 \\
(0.009)\end{array}$ & $\begin{array}{c}-0.019 * * \\
(0.008)\end{array}$ & $\begin{array}{c}-0.016^{*} \\
(0.010)\end{array}$ & $\begin{array}{l}-0.014 \\
(0.033)\end{array}$ & $-0.079 * *$ & $\begin{array}{l}-0.049 \\
(0.033)\end{array}$ \\
\hline$=1$ if lives in the city, 0 otherwise & $\begin{array}{c}-0.036^{* * *} \\
(0.008)\end{array}$ & $\begin{array}{c}-0.031 * * * \\
(0.007)\end{array}$ & $\begin{array}{c}-0.035^{* * *} \\
(0.008)\end{array}$ & $\begin{array}{c}0.117 * * * \\
(0.023)\end{array}$ & $\begin{array}{c}0.137 * * * \\
(0.023)\end{array}$ & $\begin{array}{c}0.122 * * * \\
(0.023)\end{array}$ \\
\hline $\begin{array}{l}\text { Educational attainment (base case primary and below): } \\
=1 \text { if highest education level is upper secondary, } 0 \text { otherwise } \\
=1 \text { if highest education level is post-secondary and above, } 0 \text { otherwise }\end{array}$ & $\begin{array}{l}-0.057 * * * \\
(0.007) \\
-0.147 * * * \\
(0.007)\end{array}$ & $\begin{array}{l}-0.040 * * * \\
(0.008) \\
-0.102 * * * \\
(0.009)\end{array}$ & $\begin{array}{l}-0.050 * * * \\
(0.008) \\
-0.139 * * * \\
(0.007)\end{array}$ & & & \\
\hline $\begin{array}{l}\text { Pseudo R-squared } \\
\text { Log likelihood }\end{array}$ & $\begin{array}{c}0.21 \\
-31161.22\end{array}$ & $\begin{array}{c}0.17 \\
-29675.22\end{array}$ & $\begin{array}{c}0.21 \\
-31181.12\end{array}$ & & & \\
\hline Number of id & & & & 710 & 710 & 710 \\
\hline R-squared & & & & 0.47 & 0.37 & 0.47 \\
\hline Number of observations & 57,371 & 57,371 & 57,371 & 2,035 & 2,035 & 2,035 \\
\hline
\end{tabular}


Table 4: Estimates of Opposition towards Further Immigration: The Effects of Social Security Spending and the Crime Rate

\begin{tabular}{|c|c|c|c|c|c|c|c|c|c|c|c|c|}
\hline & \multicolumn{6}{|c|}{ Pooled Probit } & \multicolumn{6}{|c|}{ Pseudo Panel } \\
\hline & \multicolumn{3}{|c|}{ Same Race } & \multicolumn{3}{|c|}{ Different Race } & \multicolumn{3}{|c|}{ Same Race } & \multicolumn{3}{|c|}{ Different Race } \\
\hline \multirow{2}{*}{$\begin{array}{l}\text { Proportion of non-nationals } \\
\text { by occupation }\end{array}$} & $0.217 * * *$ & $0.225^{* * *}$ & $0.218 * * *$ & $0.172 * * *$ & $0.187 * * *$ & $0.174 * * *$ & & & & & & \\
\hline & $(0.065)$ & $(0.064)$ & $(0.065)$ & $(0.059)$ & $(0.060)$ & $(0.059)$ & & & & & & \\
\hline \multirow[t]{2}{*}{$\begin{array}{l}\text { Proportion of non-nationals } \\
\text { by education }\end{array}$} & & & & & & & $1.038 * * *$ & $1.043 * * *$ & $1.016 * * *$ & $-0.466^{*}$ & $-0.446^{*}$ & $-0.484 *$ \\
\hline & & & & & & & $(0.268)$ & $(0.268)$ & $(0.268)$ & $(0.267)$ & $(0.268)$ & $(0.267)$ \\
\hline \multirow{2}{*}{$\begin{array}{l}\text { Proportion of non-nationals } \\
\text { by region }\end{array}$} & -0.115 & -0.113 & -0.115 & $-0.180^{*}$ & $-0.181^{*}$ & $-0.180^{*}$ & -0.080 & -0.126 & -0.073 & $-0.632 * *$ & $-0.692 * *$ & $-0.626^{* *}$ \\
\hline & $(0.092)$ & $(0.094)$ & $(0.092)$ & (0.097) & $(0.099)$ & $(0.097)$ & $(0.306)$ & $(0.306)$ & $(0.306)$ & $(0.305)$ & $(0.306)$ & $(0.305)$ \\
\hline \multirow{2}{*}{$\begin{array}{l}\text { Immigrants are bad for the } \\
\text { economy }\end{array}$} & $0.155^{* * *}$ & $0.157 * * *$ & $0.155^{* * *}$ & $0.203 * * *$ & $0.204 * * *$ & $0.202 * * *$ & $0.080 * * *$ & $0.082 * * *$ & $0.082 * * *$ & $0.157 * * *$ & $0.161 * * *$ & $0.158 * * *$ \\
\hline & $(0.009)$ & (0.009) & (0.009) & $(0.011)$ & $(0.011)$ & $(0.011)$ & $(0.026)$ & $(0.026)$ & $(0.026)$ & $(0.026)$ & $(0.026)$ & $(0.026)$ \\
\hline \multirow{2}{*}{$\begin{array}{l}\text { Immigrants are bad for the } \\
\text { county's culture }\end{array}$} & $0.122 * * *$ & $0.122 * * *$ & $0.122 * * *$ & $0.162 * * *$ & $0.162 * * *$ & $0.162 * * *$ & $0.049^{*}$ & $0.049^{*}$ & $0.051^{*}$ & $0.124 * * *$ & $0.126^{* * *}$ & $0.126 * * *$ \\
\hline & $(0.011)$ & $(0.011)$ & $(0.011)$ & $(0.009)$ & $(0.009)$ & (0.009) & $(0.029)$ & $(0.029)$ & $(0.029)$ & $(0.029)$ & $(0.029)$ & $(0.029)$ \\
\hline \multirow{2}{*}{$\begin{array}{l}\text { Immigrants are bad for the } \\
\text { country }\end{array}$} & 0.067 & $0.139 * * *$ & 0.070 & 0.006 & $0.168 * * *$ & 0.016 & $0.204 * *$ & $0.221 * * *$ & $0.234 * * *$ & 0.037 & $0.130 * *$ & 0.063 \\
\hline & $(0.053)$ & $(0.018)$ & $(0.056)$ & $(0.064)$ & $(0.022)$ & $(0.069)$ & $(0.085)$ & $(0.060)$ & $(0.087)$ & $(0.085)$ & $(0.059)$ & $(0.087)$ \\
\hline \multirow{2}{*}{$\begin{array}{l}\text { Immigrants are bad for the } \\
\text { country*SSGDP }\end{array}$} & $0.389 *$ & & 0.353 & $0.938 * * *$ & & $0.803 * *$ & 0.510 & & -0.228 & $1.169 * * *$ & & 0.539 \\
\hline & $(0.201)$ & & $(0.259)$ & $(0.249)$ & & $(0.339)$ & $(0.372)$ & & $(0.630)$ & $(0.370)$ & & $(0.628)$ \\
\hline \multirow{2}{*}{$\begin{array}{l}\text { Immigrants are bad for the } \\
\text { country*Crime rate }\end{array}$} & & $0.446^{*}$ & 0.094 & & $1.128 * * *$ & 0.351 & & $1.524 *$ & 2.182 & & $2.650 * * *$ & 1.864 \\
\hline & & $(0.254)$ & $(0.335)$ & & $(0.305)$ & $(0.435)$ & & $(0.886)$ & $(1.504)$ & & $(0.885)$ & $(1.500)$ \\
\hline Pseudo R-squared & 0.17 & 0.17 & 0.17 & 0.21 & 0.21 & 0.21 & & & & & & \\
\hline Log likelihood & -29311.21 & -29672.32 & -29311.13 & -30804.58 & -31167.71 & -30803.78 & & & & & & \\
\hline Number of id & & & & & & & 710 & 710 & 710 & 710 & 710 & 710 \\
\hline R-squared & & & & & & & 0.38 & 0.37 & 0.38 & 0.48 & 0.47 & 0.48 \\
\hline Number of observations & 56,720 & 57,371 & 56,720 & 56,720 & 57,371 & 56,720 & 2,033 & 2,035 & 2,033 & 2,033 & 2,035 & 2,033 \\
\hline
\end{tabular}


Table 5: Estimates of Opposition towards Further Immigration by Educational Attainment: Pooled Probit

\begin{tabular}{|c|c|c|c|c|c|c|}
\hline \multirow[b]{2}{*}{ Variable } & \multicolumn{3}{|c|}{ Same Race } & \multicolumn{3}{|c|}{ Different Race } \\
\hline & Primary Education & Upper Secondary & Post Secondary & Primary Education & Upper Secondary & Post Secondary \\
\hline Proportion of non-nationals by occupation & $\begin{array}{c}0.188 \\
(0117)\end{array}$ & $\begin{array}{l}0.252^{*} \\
(0.152)\end{array}$ & $0.296^{* * *}$ & 0.042 & $0.431 * * *$ & 0.200 \\
\hline \multirow[t]{2}{*}{ Proportion of non-nationals by region } & -0.187 & 0.010 & -0.102 & -0.110 & -0.048 & $-0.279 * * *$ \\
\hline & $(0.172)$ & $(0.144)$ & $(0.083)$ & $(0.121)$ & $(0.179)$ & $(0.078)$ \\
\hline \multirow[t]{2}{*}{ Immigrants are bad for the economy } & $0.163 * * *$ & $0.142 * * *$ & $0.156 * * *$ & $0.180 * * *$ & $0.181 * * *$ & $0.238 * * *$ \\
\hline & $(0.012)$ & $(0.011)$ & $(0.015)$ & $(0.013)$ & $(0.014)$ & $(0.018)$ \\
\hline \multirow[t]{2}{*}{ Immigrants are bad for the county's culture } & $0.116^{* * *}$ & $0.128 * * *$ & $0.117 * * *$ & $0.138 * * *$ & $0.150 * * *$ & $0.196 * * *$ \\
\hline & $(0.019)$ & $(0.015)$ & $(0.019)$ & $(0.018)$ & $(0.016)$ & $(0.028)$ \\
\hline Immigrants are bad for the country & $(0.012)$ & $(0.009)$ & $(0.017)$ & $(0.010)$ & $(0.011)$ & $(0.013)$ \\
\hline Pseudo R-squared & 0.13 & 0.13 & 0.17 & 0.17 & 0.18 & 0.21 \\
\hline Log likelihood & -11006.98 & -10837.10 & -7781.07 & -10523.75 & -11456.14 & -9092.40 \\
\hline Number of observations & 18,531 & 20,266 & 18,574 & 18,531 & 20,266 & 18,574 \\
\hline
\end{tabular}


Table 6: Estimates of Opposition towards Further Immigration by Groups of Countries: Pooled Probit

\begin{tabular}{|c|c|c|c|c|c|c|c|c|c|c|}
\hline \multirow{2}{*}{\begin{tabular}{l|} 
Panel A \\
Variable
\end{tabular}} & \multicolumn{5}{|c|}{ Same Race } & \multicolumn{5}{|c|}{ Different Race } \\
\hline & All & All & Primary & Upper Sec. & Post Secondary & All & All & Primary & Upper Sec. & Post Secondary \\
\hline Proportion of non-nationals by occupation & $\begin{array}{c}0.424 * * * * \\
(0.145)\end{array}$ & $\begin{array}{c}0.414 * * * \\
(0.147)\end{array}$ & $\begin{array}{c}0.653 * * * \\
(0.206)\end{array}$ & $\begin{array}{c}0.225 \\
(0.206)\end{array}$ & $\begin{array}{c}0.467^{* *} \\
(0.188)\end{array}$ & $\begin{array}{c}0.367 * * * \\
(0.115)\end{array}$ & $\begin{array}{c}0.358^{* * * *} \\
(0.116)\end{array}$ & $\begin{array}{c}0.176 \\
(0.150)\end{array}$ & $\begin{array}{c}0.550 * * * \\
(0.170)\end{array}$ & $\begin{array}{c}0.398 \\
(0.244)\end{array}$ \\
\hline Proportion of non-nationals by region & $\begin{array}{c}-0.160 * * \\
(0.066)\end{array}$ & $\begin{array}{c}-0.157 * * \\
(0.065)\end{array}$ & $\begin{array}{l}-0.260 \\
(0.168)\end{array}$ & $\begin{array}{l}-0.148 \\
(0.154)\end{array}$ & $\begin{array}{l}-0.060 \\
(0.100)\end{array}$ & $\begin{array}{c}-0.256^{* *} \\
(0.112)\end{array}$ & $\begin{array}{c}-0.254 * * \\
(0.111)\end{array}$ & $\begin{array}{l}-0.212 \\
(0.144)\end{array}$ & $\begin{array}{l}-0.219 \\
(0.200)\end{array}$ & $\begin{array}{c}-0.244 * * * \\
(0.085)\end{array}$ \\
\hline Immigrants are bad for the economy & $\begin{array}{c}0.143^{* * * *} \\
(0.010)\end{array}$ & $\begin{array}{c}0.143 * * * \\
(0.010)\end{array}$ & $\begin{array}{c}0.143 * * * \\
(0.013)\end{array}$ & $\begin{array}{c}0.131 * * * \\
(0.015)\end{array}$ & $\begin{array}{c}0.148^{* * * *} \\
(0.018)\end{array}$ & $\begin{array}{c}0.196 * * * \\
(0.012)\end{array}$ & $\begin{array}{c}0.196^{* * *} * \\
(0.012)\end{array}$ & $\begin{array}{c}0.168 * * * \\
(0.016)\end{array}$ & $\begin{array}{c}0.165^{* * * *} \\
(0.018)\end{array}$ & $\begin{array}{c}0.235^{* * *} \\
(0.019)\end{array}$ \\
\hline Immigrants are bad for the country's culture & $\begin{array}{c}0.125 * * * \\
(0.013)\end{array}$ & $\begin{array}{c}0.125 * * * * \\
(0.013)\end{array}$ & $\begin{array}{c}0.120 * * * * \\
(0.023)\end{array}$ & $\begin{array}{c}0.139 * * * \\
(0.019)\end{array}$ & $\begin{array}{c}0.117 * * * * \\
(0.025)\end{array}$ & $\begin{array}{c}0.159^{* * * *} \\
(0.011)\end{array}$ & $\begin{array}{c}0.160 * * * * \\
(0.011)\end{array}$ & $\begin{array}{c}0.129 * * * \\
(0.020)\end{array}$ & $\begin{array}{c}0.146 * * * \\
(0.023)\end{array}$ & $\begin{array}{c}0.202 * * * \\
(0.031)\end{array}$ \\
\hline $\begin{array}{l}\text { Immigrants are bad for the country } \\
\text { Immigrants are bad for the country*SSGDP }\end{array}$ & $\begin{array}{c}0.179 * * * \\
(0.009)\end{array}$ & $\begin{array}{c}-0.107 \\
(0.164) \\
1.022 \\
(0.630) \\
\end{array}$ & $\begin{array}{c}0.189 * * * \\
(0.015)\end{array}$ & $\begin{array}{c}0.176 * * * \\
(0.012)\end{array}$ & $\begin{array}{c}0.165^{* * * *} \\
(0.022)\end{array}$ & $\begin{array}{c}0.260 * * * \\
(0.010)\end{array}$ & $\begin{array}{c}-0.056 \\
(0.188) \\
1.149^{*} \\
(0.693) \\
\end{array}$ & $\begin{array}{c}0.209^{* * * *} \\
(0.020)\end{array}$ & $\begin{array}{c}0.276^{* * * *} \\
(0.012)\end{array}$ & $\begin{array}{c}0.260 * * * \\
(0.019)\end{array}$ \\
\hline Pseudo R-squared & 0.16 & 0.16 & 0.11 & 0.12 & 0.17 & 0.20 & 0.20 & 0.14 & 0.17 & 0.21 \\
\hline Log likelihood & -11336.68 & -11334.10 & -3617.96 & -4191.96 & -3485.33 & -12009.08 & -12006.82 & -3418.71 & -4468.54 & -4065.87 \\
\hline Number of observations & 21,882 & 21,882 & 5,950 & 7,721 & 8,211 & 21,882 & 21,882 & 5,950 & 7,721 & 8,211 \\
\hline
\end{tabular}

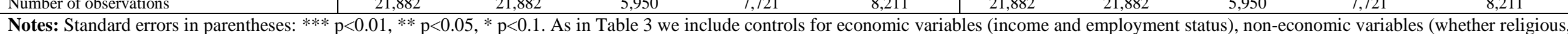

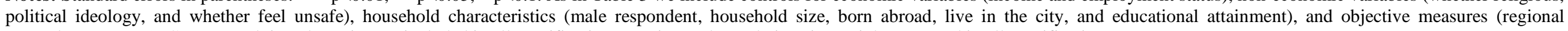
unemployment rate). Country and time dummies are included in all specifications. Design and population size weights are used in all specifications.

\begin{tabular}{|c|c|c|c|c|c|c|c|c|c|c|}
\hline \multirow{2}{*}{\begin{tabular}{l|l} 
Panel B \\
Variable \\
\end{tabular}} & \multicolumn{5}{|c|}{ Same Race } & \multicolumn{5}{|c|}{ Different Race } \\
\hline & All & All & Primary & Upper Sec. & Post Secondary & All & All & Primary & Upper Sec. & Post Secondary \\
\hline \multirow[t]{2}{*}{ Proportion of non-nationals by occupation } & -0.035 & 0.002 & -0.192 & $0.509 * *$ & -0.192 & -0.053 & -0.026 & $-0.189 *$ & 0.200 & -0.147 \\
\hline & $(0.081)$ & $(0.084)$ & $(0.126)$ & $(0.257)$ & $(0.429)$ & $(0.082)$ & $(0.084)$ & $(0.103)$ & $(0.262)$ & $(0.432)$ \\
\hline \multirow[t]{2}{*}{ Proportion of non-nationals by region } & -0.002 & 0.021 & -0.350 & $1.147 * * *$ & -0.357 & 0.201 & 0.219 & -0.106 & $1.240 * *$ & -0.124 \\
\hline & $(0.359)$ & $(0.353)$ & $(0.382)$ & $(0.364)$ & $(0.516)$ & $(0.368)$ & $(0.370)$ & $(0.335)$ & $(0.568)$ & $(0.562)$ \\
\hline Immigrants are bad for the economy & $\begin{array}{c}0.177 * * * \\
(0.018)\end{array}$ & $\begin{array}{c}0.165 * * * \\
(0.022)\end{array}$ & $\begin{array}{c}0.145^{* * *} \\
(0.028)\end{array}$ & $\begin{array}{c}0.193 * * * \\
(0.042)\end{array}$ & $\begin{array}{c}0.296 * * * \\
(0.064)\end{array}$ & $\begin{array}{c}0.207 * * * \\
(0.019)\end{array}$ & $\begin{array}{c}0.197 * * * \\
(0.021)\end{array}$ & $\begin{array}{c}0.162 * * * \\
(0.025)\end{array}$ & $\begin{array}{c}0.204 * * * \\
(0.051)\end{array}$ & $\begin{array}{c}0.377 * * * \\
(0.062)\end{array}$ \\
\hline Immigrants are bad for the country's culture & $\begin{array}{c}0.102 * * * \\
(0.020)\end{array}$ & $\begin{array}{c}0.110^{* * * *} \\
(0.020)\end{array}$ & $\begin{array}{c}0.102 * * * \\
(0.027)\end{array}$ & $\begin{array}{c}0.099 * * \\
(0.039)\end{array}$ & $\begin{array}{l}0.120 * \\
(0.067)\end{array}$ & $\begin{array}{c}0.148^{* * *} \\
(0.025)\end{array}$ & $\begin{array}{c}0.150 * * * \\
(0.026)\end{array}$ & $\begin{array}{c}0.133 * * * \\
(0.027)\end{array}$ & $\begin{array}{c}0.147 * * * \\
(0.046)\end{array}$ & $\begin{array}{c}0.179 * * * \\
(0.042)\end{array}$ \\
\hline \multirow{3}{*}{$\begin{array}{l}\text { Immigrants are bad for the country } \\
\text { Immigrants are bad for the country*SSGDP }\end{array}$} & $0.181 * * *$ & $0.209^{*}$ & $0.186^{* * *}$ & $0.167 * * *$ & $0.126 * * *$ & $0.213 * * *$ & -0.001 & $0.197 * * *$ & $0.229 * * *$ & $0.190 * * *$ \\
\hline & $(0.020)$ & $(0.121)$ & $(0.024)$ & $(0.033)$ & $(0.040)$ & $(0.016)$ & $(0.103)$ & $(0.019)$ & $(0.037)$ & $(0.045)$ \\
\hline & & $\begin{array}{l}-0.123 \\
(0.537)\end{array}$ & & & & & $\begin{array}{c}1.065^{* *} \\
(0.440)\end{array}$ & & & \\
\hline Pseudo R-squared & 0.16 & 0.16 & 0.12 & 0.17 & 0.19 & 0.21 & 0.21 & 0.17 & 0.24 & 0.24 \\
\hline Log likelihood & -5744.18 & -5361.32 & -3322.80 & -1215.80 & -1073.67 & -5399.52 & -5039.10 & -3028.49 & -1152.73 & -1078.27 \\
\hline Number of observations & 9,921 & 9,270 & 5,485 & 2,190 & 2,246 & 9,921 & 9,270 & 5,485 & 2,190 & 2,246 \\
\hline
\end{tabular}




\begin{tabular}{|c|c|c|c|c|c|c|c|c|c|c|}
\hline \multirow{2}{*}{$\begin{array}{l}\text { Panel C } \\
\text { Variable } \\
\end{array}$} & \multicolumn{5}{|c|}{ Same Race } & \multicolumn{5}{|c|}{ Different Race } \\
\hline & All & All & Primary & Upper Sec. & Post Secondary & All & All & Primary & Upper Sec. & Post Secondary \\
\hline Proportion of non-nationals by occupation & $\begin{array}{c}0.334 * * * \\
(0.115)\end{array}$ & $\begin{array}{c}0.338 * * * \\
(0.114)\end{array}$ & $\begin{array}{l}-0.127 \\
(0.420)\end{array}$ & $\begin{array}{c}0.281 \\
(0.205)\end{array}$ & $\begin{array}{c}0.638^{* * * *} \\
(0.184)\end{array}$ & $\begin{array}{ll}0.048 \\
(0.180)\end{array}$ & $\begin{array}{c}0.026 \\
(0.194)\end{array}$ & $\begin{array}{l}-0.236 \\
(0.623)\end{array}$ & 0.190 & 0.030 \\
\hline Proportion of non-nationals by region & $\begin{array}{c}-8.273 * * * * \\
(2.300)\end{array}$ & $\begin{array}{l}-8.252 * * * \\
(2.288)\end{array}$ & $\begin{array}{c}-0.731 \\
(16.380)\end{array}$ & $\begin{array}{c}-8.259^{* * * *} \\
(2.115)\end{array}$ & $\begin{array}{c}-9.586 * * * * \\
(2.910)\end{array}$ & $\begin{array}{l}-3.820 \\
(2.332)\end{array}$ & $\begin{array}{l}-3.854^{*} \\
(2.326)\end{array}$ & $\begin{array}{c}-16.330^{* * *} \\
(8.161)\end{array}$ & $\begin{array}{l}-0.928 \\
(3.368)\end{array}$ & $\begin{array}{c}-9.479 * * \\
(3.729)\end{array}$ \\
\hline Immigrants are bad for the economy & $\begin{array}{c}0.189 * * * \\
(0.015)\end{array}$ & $\begin{array}{c}0.189 * * * \\
(0.015)\end{array}$ & $\begin{array}{c}0.223 * * * \\
(0.030)\end{array}$ & $\begin{array}{c}0.168 * * * \\
(0.029)\end{array}$ & $\begin{array}{c}0.165 * * * \\
(0.028)\end{array}$ & $\begin{array}{c}0.205 * * * \\
(0.020)\end{array}$ & $\begin{array}{c}0.205 * * * * \\
(0.020)\end{array}$ & $\begin{array}{c}0.194 * * * \\
(0.038)\end{array}$ & $\begin{array}{c}0.214 * * * \\
(0.024)\end{array}$ & $\begin{array}{c}0.193 * * * \\
(0.037)\end{array}$ \\
\hline Immigrants are bad for a country's culture & $\begin{array}{c}0.129 * * * \\
(0.039)\end{array}$ & $\begin{array}{c}0.129 * * * \\
(0.039)\end{array}$ & $\begin{array}{l}0.102^{*} \\
(0.053)\end{array}$ & $\begin{array}{c}0.121 * * * \\
(0.042)\end{array}$ & $\begin{array}{c}0.225 * * * \\
(0.076)\end{array}$ & $\begin{array}{c}0.162 * * * \\
(0.041)\end{array}$ & $\begin{array}{c}0.162 * * * \\
(0.040)\end{array}$ & $\begin{array}{c}0.189 * * * \\
(0.061)\end{array}$ & $\begin{array}{c}0.145^{* * * *} \\
(0.040)\end{array}$ & $\begin{array}{c}0.140^{* *} \\
(0.056)\end{array}$ \\
\hline $\begin{array}{l}\text { Immigrants are bad for the country } \\
\text { Immigrants are bad for the country*SSGDP }\end{array}$ & $\begin{array}{l}0.120 * * * \\
(0.026)\end{array}$ & $\begin{array}{c}0.022 \\
(0.106) \\
0.463 \\
(0.559) \\
\end{array}$ & $\begin{array}{c}0.179 * * * \\
(0.049)\end{array}$ & $\begin{array}{c}0.070 * * * \\
(0.026)\end{array}$ & $\begin{array}{l}0.094^{*} \\
(0.050)\end{array}$ & $\begin{array}{c}0.141 * * * \\
(0.033)\end{array}$ & $\begin{array}{c}0.334 * * \\
(0.157) \\
-0.962 \\
(0.905) \\
\end{array}$ & $\begin{array}{c}0.129 * * \\
(0.051)\end{array}$ & $\begin{array}{c}0.131 * * * \\
(0.043)\end{array}$ & $\begin{array}{c}0.185 * * * \\
(0.059)\end{array}$ \\
\hline Pseudo R-squared & 0.17 & 0.17 & 0.16 & 0.15 & 0.23 & 0.16 & 0.16 & 0.14 & 0.17 & 0.16 \\
\hline Log likelihood & -3737.39 & -3737.17 & -1188.98 & -1882.53 & -549.17 & -4247.74 & -4247.07 & -1319.17 & -2065.38 & -760.05 \\
\hline Number of observations & 7,591 & 7,591 & 2,238 & 3,776 & 1,577 & 7,591 & 7,591 & 2,238 & 3,776 & 1,577 \\
\hline
\end{tabular}

\begin{tabular}{|c|c|c|c|c|c|c|c|c|c|c|}
\hline Panel D & & & Same Race & & & & & Different & & \\
\hline Variable & All & All & Primary & Upper Sec. & $\begin{array}{c}\text { Post } \\
\text { Secondary }\end{array}$ & All & $\begin{array}{l}\text { Whole } \\
\text { sample }\end{array}$ & Primary & Upper Sec. & Post Secondary \\
\hline Proportion of non-nationals by occupation & $\begin{array}{l}0.321 * * \\
(0.129)\end{array}$ & $\begin{array}{c}0.306^{* * *} \\
(0.129)\end{array}$ & $\begin{array}{l}0.180 \\
(0.429)\end{array}$ & $\begin{array}{c}0.743 * * \\
(0.322)\end{array}$ & $\begin{array}{l}-0.011 \\
(0.129)\end{array}$ & $\begin{array}{c}0.185 \\
(0.244)\end{array}$ & $\begin{array}{c}0.179 \\
(0.245)\end{array}$ & $\begin{array}{c}0.096 \\
(0.584)\end{array}$ & $\begin{array}{c}0.973 * * * \\
(0.240)\end{array}$ & $\begin{array}{l}-0.608 \\
(0.429)\end{array}$ \\
\hline Proportion of non-nationals by region & $\begin{array}{c}-0.511^{* *} \\
(0.212)\end{array}$ & $\begin{array}{c}-0.481 * * \\
(0.200)\end{array}$ & $\begin{array}{l}-0.493 \\
(0.571)\end{array}$ & $\begin{array}{l}-0.447 \\
(0.273)\end{array}$ & $\begin{array}{c}-0.488^{* * *} \\
(0.119)\end{array}$ & $\begin{array}{c}-0.756^{* *} \\
(0.348)\end{array}$ & $\begin{array}{c}-0.749^{* *} \\
(0.346)\end{array}$ & $\begin{array}{l}-0.722 \\
(0.766)\end{array}$ & $\begin{array}{c}-0.550^{*} \\
(0.322)\end{array}$ & $\begin{array}{c}-1.051 * * * \\
(0.324)\end{array}$ \\
\hline Immigrants are bad for the economy & $\begin{array}{c}0.143 * * * \\
(0.006)\end{array}$ & $\begin{array}{c}0.141 * * * \\
(0.008)\end{array}$ & $\begin{array}{c}0.174 * * * \\
(0.011)\end{array}$ & $\begin{array}{c}0.146 * * * \\
(0.009)\end{array}$ & $\begin{array}{c}0.112 * * * \\
(0.012)\end{array}$ & $\begin{array}{c}0.214 * * * \\
(0.008)\end{array}$ & $\begin{array}{c}0.213 * * * * \\
(0.007)\end{array}$ & $\begin{array}{c}0.218 * * * \\
(0.016)\end{array}$ & $\begin{array}{c}0.212 * * * \\
(0.012)\end{array}$ & $\begin{array}{c}0.204 * * * \\
(0.014)\end{array}$ \\
\hline Immigrants are bad for the country's culture & $\begin{array}{c}0.080 * * * \\
(0.015)\end{array}$ & $\begin{array}{c}0.075 * * * \\
(0.015)\end{array}$ & $\begin{array}{c}0.113 * * * \\
(0.011)\end{array}$ & $\begin{array}{c}0.084 * * * \\
(0.016)\end{array}$ & $\begin{array}{c}0.047 \\
(0.029)\end{array}$ & $\begin{array}{c}0.182 * * * \\
(0.011)\end{array}$ & $\begin{array}{c}0.180^{* * * *} \\
(0.011)\end{array}$ & $\begin{array}{c}0.150 * * * \\
(0.024)\end{array}$ & $\begin{array}{c}0.192 * * * \\
(0.011)\end{array}$ & $\begin{array}{c}0.204 * * * \\
(0.021)\end{array}$ \\
\hline $\begin{array}{l}\text { Immigrants are bad for the country } \\
\text { Immigrants are bad for the country*SSGDP }\end{array}$ & $\begin{array}{c}0.140^{* * * *} \\
(0.013)\end{array}$ & $\begin{array}{c}-0.161 * \\
(0.086) \\
1.182 * * \\
(0.506)\end{array}$ & $\begin{array}{c}0.167 * * * \\
(0.042)\end{array}$ & $\begin{array}{c}0.140^{* * * *} \\
(0.015)\end{array}$ & $\begin{array}{c}0.121^{* * * *} \\
(0.011)\end{array}$ & $\begin{array}{c}0.303 * * * \\
(0.025)\end{array}$ & $\begin{array}{c}0.151 \\
(0.125) \\
0.523 \\
(0.358)\end{array}$ & $\begin{array}{c}0.269 * * * \\
(0.026)\end{array}$ & $\begin{array}{c}0.302 * * * \\
(0.030)\end{array}$ & $\begin{array}{c}0.340^{* * * *} \\
(0.032)\end{array}$ \\
\hline $\begin{array}{l}\text { Pseudo R-squared } \\
\text { Log likelihood } \\
\text { Number of observations }\end{array}$ & $\begin{array}{c}0.20 \\
-7538.36 \\
17,977\end{array}$ & $\begin{array}{c}0.20 \\
-7524.17 \\
17,977\end{array}$ & $\begin{array}{c}0.21 \\
-2326.73 \\
4,858\end{array}$ & $\begin{array}{c}0.16 \\
-3096.27 \\
6,579\end{array}$ & $\begin{array}{c}0.18 \\
-2080.98 \\
6,540\end{array}$ & $\begin{array}{c}0.30 \\
-8344.38 \\
17,977\end{array}$ & $\begin{array}{c}0.30 \\
-8343.16 \\
17,977\end{array}$ & $\begin{array}{c}0.31 \\
-2307.55 \\
4,858\end{array}$ & $\begin{array}{c}0.28 \\
-3250.00 \\
6,579\end{array}$ & $\begin{array}{c}0.30 \\
-2721.00 \\
6,540\end{array}$ \\
\hline
\end{tabular}


Table 7: Estimates of Opposition towards Further Immigration: Robustness

\begin{tabular}{|c|c|c|c|c|c|c|c|c|c|c|}
\hline \multirow[b]{2}{*}{ Variable } & \multicolumn{3}{|c|}{ Pooled Probit } & \multicolumn{3}{|c|}{ Pseudo panel } & \multicolumn{2}{|c|}{$\begin{array}{l}\text { Pooled probit: Social Welfare } \\
\text { Implications }\end{array}$} & \multicolumn{2}{|c|}{$\begin{array}{l}\text { Pseudo panel: Social Welfare } \\
\text { Implications }\end{array}$} \\
\hline & All & Same Race & Different Race & All & Same Race & Different Race & Same Race & Different Race & Same Race & Different Race \\
\hline $\begin{array}{l}\text { Proportion of non- nationals by } \\
\text { Occupation }\end{array}$ & $\begin{array}{c}0.401^{* * *} \\
(0.058)\end{array}$ & $\begin{array}{c}0.383^{* * * *} \\
(0.064)\end{array}$ & $\begin{array}{c}0.402 * * * \\
(0.055)\end{array}$ & & & & $\begin{array}{c}0.279^{* * *} \\
(0.071)\end{array}$ & $\begin{array}{c}0.266^{* * * *} \\
(0.056)\end{array}$ & & \\
\hline Proportion of non- nationals by & $-0.301 * * *$ & $-0.204 *$ & $-0.280^{* *}$ & $-1.118 * * *$ & -0.384 & $-0.982 * * *$ & -0.143 & $-0.210^{* *}$ & -0.057 & $-0.609 *$ \\
\hline Region & $(0.117)$ & $(0.106)$ & $(0.115)$ & $(0.343)$ & $(0.333)$ & $(0.345)$ & $(0.098)$ & $(0.104)$ & $(0.309)$ & $(0.314)$ \\
\hline Proportion of non-nationals by & & & & -0.178 & $0.958 * * *$ & -0.475 & & & $0.996 * * *$ & -0.441 \\
\hline Education & & & & $(0.295)$ & $(0.287)$ & $(0.297)$ & & & $(0.266)$ & $(0.270)$ \\
\hline $\begin{array}{l}\text { Immigrants are bad for the } \\
\text { country *SSGDP }\end{array}$ & & & & & & & $\begin{array}{c}1.080 * * * \\
(0.082)\end{array}$ & $\begin{array}{c}1.413 * * * \\
(0.116)\end{array}$ & $\begin{array}{c}1.448 * * * \\
(0.420)\end{array}$ & $\begin{array}{c}1.754 * * * \\
(0.427)\end{array}$ \\
\hline Immigrants are bad for the & & & & & & & $\begin{array}{l}(0.082) \\
-0.050\end{array}$ & $\begin{array}{c}(0.116) \\
0.309\end{array}$ & $\begin{array}{c}(0.420) \\
0.567\end{array}$ & $\begin{array}{c}(0.427) \\
0.275\end{array}$ \\
\hline country $*$ Crime rate & & & & & & & $(0.323)$ & $(0.398)$ & $(1.466)$ & $(1.489)$ \\
\hline Pseudo R-squared & 0.0941 & 0.0790 & 0.0917 & & & & 0.142 & 0.178 & & \\
\hline Log likelihood & -35946 & -32925 & -35893 & & & & -30279 & -32090 & & \\
\hline Number of observations & & & & 710 & 710 & 710 & & & 710 & 710 \\
\hline R-squared & & & & 0.326 & 0.253 & 0.322 & & & 0.364 & 0.445 \\
\hline Number of observations & 57,371 & 57,371 & 57,371 & 2,035 & 2,035 & 2,035 & 56,720 & 56,720 & 2,033 & 2,033 \\
\hline \multicolumn{11}{|c|}{ 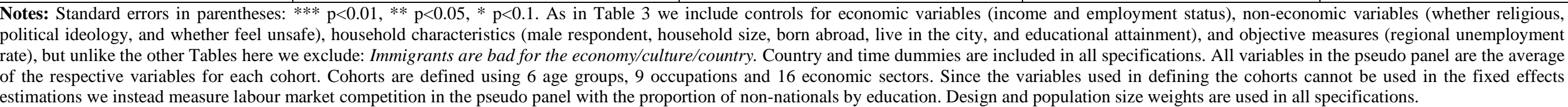 } \\
\hline
\end{tabular}

